\title{
Properties and Rundown of Sodium-activated Potassium Channels in Rat Olfactory Bulb Neurons
}

\author{
Terrance M. Egan, Daniel Dagan, ${ }^{a}$ Jürgen Kupper, and Irwin B. Levitan \\ Graduate Department of Biochemistry and Center for Complex Systems, Brandeis University, Waltham, \\ Massachusetts 02254-9110
}

\begin{abstract}
We have used single-channel recording techniques to investigate the properties of sodium-activated potassium channels ( $K_{\mathrm{N},}$ channels) in cultured rat olfactory bulb neurons, and in large neurons in the mitral cell layer of thin slices of olfactory bulb. Ion channels highly selective for potassium over sodium and chloride, and requiring 10-180 $\mathrm{mm}$ internal sodium $\left(\mathrm{Na}_{1}\right)$ for their activation, were present in approximately $\mathbf{7 5} \%$, of inside-out membrane patches detached from cultured olfactory bulb neurons. Most of these patches contained several $K_{\mathrm{m}}$ channels. $K_{\mathrm{Na}}$ channels were seen in cellattached patches only when $\mathrm{Na}$, was raised by including veratridine in the extracellular medium. Preincubation of the cell in TTX or removal of extracellular sodium prevented this effect of veratridine, confirming that the channels observed under these conditions were indeed $K_{\mathrm{m}}$ channels. Lithium did not substitute for $\mathrm{Na}_{\text {, }}$ in activating these channels. With $150 \mathrm{~mm}$ potassium on both sides of the membrane, $K_{\mathrm{N} .}$ channels had a single-channel conductance of $172 \mathrm{pS}$, and at least two subconducting states were observed in addition to this fully open state. Under these ionic conditions, the channels exhibited linear fully open channel current-voltage curves over the potential range of -100 to $0 \mathrm{mV}$. At voltages more positive than the potassium equilibrium potential, the single-channel currents exhibited inward rectification as a result of sodium block of outward potassium current. The channels opened in bursts, during which they fluctuated between the fully open and closed states, and the substates. Between bursts they sometimes entered a long-lived inactive state that could last for up to several minutes. In addition, $K_{\mathrm{N}}$ channels in the detached patches exhibited rundown, a progressive irreversible loss in activity, over a time course that varied from less than 1 min to longer than $1 \mathrm{hr}$. Rundown of $K_{\mathrm{Na}}$ channel activity in cell-attached patches (in the presence of veratridine) did not occur, suggesting that some intracellular factor necessary for $K_{\mathrm{Na}}$ channel activity is lost when the membrane patch is detached from the cell.
\end{abstract}

\footnotetext{
Received Sept. 11, 1991; revised Dec. 26, 1991; accepted Dec. 30, 1991.

We thank Richard Baughman and James Huettner for supplying us with a detailed report of their culture method, Marcel Bolgers and Janssen Research Foundation for the gift of R58735 (sabeluzole) and R56865, and Stephen Smith for the loan of the $40 \times$ water immersion lens. We also thank Peter Reinhart and John Dempster for their analysis programs, and Paul Katz, Chris Miller, and Peter Reinhart for reading the manuscript. This work was supported by NIH Grant NSI 7910 to I.B.L.

Correspondence should be addressed to Dr. Irwin B. Levitan, Graduate Department of Biochemistry, Brandeis University, Waltham, MA 02254-9110.

- Permanent address: Rappaport Family Institute, Technion Faculty of Medicine, Department of Physiology and Biophysics, Haifa 30197, Israel.

Copyright (C) 1992 Society for Neuroscience $0270-6474 / 92 / 121964-13 \$ 05.00 / 0$
}

Many different types of $\mathrm{K}^{+}$channels have been characterized in neurons by electrophysiological techniques, and the recent application of molecular genetic approaches has emphasized the enormous diversity of the $\mathrm{K}^{+}$channel family. Within this large family of $\mathrm{K}^{+}$channels, one class is modulated by cations. The best known examples of this class are the $\mathrm{Ca}^{2+}$-activated $\mathrm{K}^{+}$ channels ( $\mathrm{K}_{\mathrm{C}_{\mathrm{a}}}$ channels) (Latorre et al., 1989). Recent evidence has shown that $\mathrm{Na}^{+}$, also can activate a $\mathrm{K}^{+}$channel. Such $\mathrm{K}_{\mathrm{Na}}$ channels have been reported in snail neurons (Partridge and Thomas, 1976), vertebrate heart (Kameyama et al., 1984; Luk and Carmeliet, 1990; Wang et al., 1991), cultured quail trigeminal neurons (Bader et al., 1985; Haimann et al., 1990), crayfish neurons (Hartung, 1985), Drosophila giant neurons (Saito and Wu, 1991), zebra finch hyperstriatal neurons (Kubota and Saito, 1991), and cultured chick brainstem neurons (Dryer et al., 1989). Voltage-clamp analysis of currents of guinea pig and rat suggests that the $\mathrm{K}_{\mathrm{Na}}$ channel is also present in mammalian brain (Constanti and Sim, 1987; Schwindt et al., 1989), but thus far no single-channel analysis of $\mathrm{K}_{\mathrm{Na}}$ channels from mammalian brain has been reported.

We have becn interested in the properties of cation-sensitive $\mathrm{K}^{+}$channels in mammalian brain and have focused our attention on the rat olfactory bulb. The behavior of the olfactory bulb is determined in part by the electrical activity of the different populations of neurons that comprise it (Shepherd and Greer, 1990). Soon after an odor is detected by the sensory neurons, action potential discharge begins in the principal relay cells of the bulb, the mitral cells (Macrides and Chorover, 1972; Kauer, 1974, 1987, 1991; Hamilton and Kaucr, 1985; Meredith, 1986; Doving, 1987; Wellis et al., 1989; Wellis and Scott, 1990). The pattern and intensity of this discharge are determined by the actions of local circuits (Kauer, 1974; Mair, 1982; Scott and Harrison, 1987; Hamilton and Kauer, 1989) and by the inherent ionic conductances of the neurons (Yamamoto et al., 1963; Jahr and Nicoll, 1982; Mori, 1987). A major component of these conductances is likely the result of the activity of $\mathrm{K}^{+}$channels.

Most of the information available about the pharmacology and neurophysiology of the olfactory bulb comes from in vitro brain slice preparations of turtle and salamander and from in vivo studies on rabbit and salamander, although an in vitro preparation of rat olfactory bulb has been developed (Frosch and Dichter, 1984; Trombley and Westbrook, 1990). We used two in vitro preparations of rat olfactory bulb, thin brain slices and dissociated neurons in primary culture, to study the properties of $\mathrm{K}^{+}$-selective ion channels. The activity of one type of $\mathrm{K}^{+}$ channel in these preparations is dependent on $\left[\mathrm{Na}^{+}\right]_{i}$. We studied the behavior of this channel using both the cell-attached con- 
figuration of the patch clamp technique while indirectly varying $\left[\mathrm{Na}^{+}\right]$, (with veratridine), and the cell-detached inside-out and outside-out configurations, which allow more direct control of ion concentration gradients.

A preliminary report of this work has been presented to the Biophysical Society (Egan et al., 1990).

\section{Materials and Methods}

Tissue culture. Primary cultures of postnatal rat central neurons were prepared according to the method of Huettner and Baughman (Huettner and Baughman, 1986; Baughman et al., 1991). Long-Evans rat pups, aged $1-3 \mathrm{~d}$, were killed by decapitation. The main and accessory olfactory bulbs were quickly removed from the cranium and cut into thirds with a razor blade. The resulting approximately $1-\mathrm{mm}$-thick slices were bathed in $3 \mathrm{ml}$ of a physiological saline solution containing $1 \mathrm{~mm}$ free $\mathrm{Ca}^{2+}$, papain (Worthington Biochemicals; 150-250 U), cysteine (1 $\mathrm{mm}$ ), and kynurenic acid $(0.1-1 \mathrm{~mm})$ and kept at a temperature of $37^{\circ} \mathrm{C}$ in a $5 \% \mathrm{CO}_{2}$ incubator. After $30 \mathrm{~min}$, the bath solution was replaced with $3 \mathrm{ml}$ of fresh enzyme solution and left for an additional $30 \mathrm{~min}$. This procedure was repeated again so that the slices were incubated in enzyme for a total of $90 \mathrm{~min}$. The slices were then washed in a solution containing $5 \%$ fetal calf serum, bovine serum albumin $(1 \mathrm{mg} / \mathrm{ml})$, and trypsin inhibitor $(1 \mathrm{mg} / \mathrm{ml}$; Boehringer Mannheim) to stop the enzymatic action of the papain. Cells were dissociated by triturating the slices with firepolished Pasteur pipettes, and the dispersed neurons and glia were plated onto collagen-coated glass cover slips. The cultures were kept at $37^{\circ} \mathrm{C}$ in a humid atmosphere containing $5 \% \mathrm{CO}_{2}$. Typically, four pups were used per preparation, yielding about 48 culture plates. The growth medium was Dulbecco's modified Eagle medium containing glutamine $(0.5$ $\mathrm{mM})$, glucose $(20 \mathrm{~mm})$, penicillin $(100 \mathrm{U} / \mathrm{ml})$, streptomycin $(0.1 \mathrm{mg} / \mathrm{ml})$, $5 \%$ fetal calf serum (all from GIBCO Laboratories), and kynurenic acid (0.1-1 mM). Cytosine arabinoside (10-20 $\mu \mathrm{M})$ was added for $24-48 \mathrm{hr}$ between days 3 and 5 to stop overgrowth of rapidly dividing cells. The medium was exchanged every $5 \mathrm{~d}$. Neurons were viable under these conditions for at least 2 months, and ion channel activity could be recorded from cultures prepared the previous day. We used neurons maintained in culture for 7-21 d for the experiments described in this paper. Except where otherwise noted, chemicals were obtained from Sigma Chemicals.

Brain slices. Thin brain slices were prepared according to the method of Edwards et al. (1989). Long-Evans rats, aged 14-21 d, were killed by decapitation. The cranium was quickly submerged in a cool $\left(4^{\circ} \mathrm{C}\right)$ saline solution of the following composition (in mM): $125 \mathrm{NaCl}, 2.5$ $\mathrm{KCl}, 2 \mathrm{CaCl}_{2}, 2 \mathrm{MgCl}_{2}, 26 \mathrm{NaHCO}_{3}, 1.25 \mathrm{NaH}_{2} \mathrm{PO}_{4}, 25$ glucose, gassed with $95 \% \mathrm{O}_{2} / 5 \% \mathrm{CO}_{2}$. One main olfactory bulb/accessory olfactory bulb complex along with a small portion (3-5 mm) of the attached frontal cortex was dissected from the rest of the brain. The frontal cortex was used as a base to stabilize the sausage-shaped bulbs during slicing. The bulb/frontal cortex was then fastened to the stage of a vibrating microtome (TPI Vibratome 1000) with a drop of cyanoacrylic glue. The Vibratome bath also contained the cool, gassed saline. Depending on how the hulb/cortex complex was positioned on the stage, either horizontal or coronal slices were obtained. The first cut removed the uppermost quarter of the bulb, which was discarded. Then, successive $120-150-\mu \mathrm{m}$-thick slices were cut until a total of 5-10 slices was obtained. The slices were transferred to a holding chamber containing the same oxygenated physiological saline solution at room temperature. The slices remained viable under these conditions for at least $8 \mathrm{hr}$. A single slice was transferred to a tissue bath positioned on the fixed stage of a Zeiss ACM microscope, and cells were visualized with Nomarski optics using a $40 \times$ water immersion lens. Total magnification equaled $400 \times$. Mitral and granule cells were identified by their location in the slice. Individual neurons were cleaned with a micropipette by the technique described by Edwards et al. (1989). The pipette solution contained (in mM) $125 \mathrm{NaCl}, 2.5 \mathrm{KCl}, 26 \mathrm{NaHCO}_{3}, 1.25 \mathrm{NaH}_{2} \mathrm{PO}_{4}$, and 10 EDTA; we found that the inclusion of EDTA and the exclusion of divalent cations helped prevent clogging of the pipette tip with debris during the cleaning process.

Electrophysiology. $\mathrm{K}_{\mathrm{Na}}$ channels were recorded from on-cell, insideout, and outside-out patches of olfactory bulb neurons using conventional methods (Hamill et al., 1981). Unless otherwise noted, data presented here come from experiments using the inside-out patch clamp configuration on olfactory bulb neuronal cultures. Patch electrodes were pulled from $1.5 \mathrm{~mm}$ o.d. borosilicate glass capillary tubes (Jencons $\mathrm{H} 15$ ). The electrodes were lightly fire-polished to a final tip diameter of 1-2 $\mu \mathrm{m}$ and had resistances of 2-10 M 2 when filled with $150 \mathrm{~mm} \mathrm{~K} \mathrm{~K}^{+}$salts. Single-channel activity was recorded with a List EPC-7 or an Axopatch 1-D amplifier using a headstage gain of $50 \mathrm{mV} / \mathrm{pA}$. A head stage gain of $10-20 \mathrm{mV} / \mathrm{pA}$ was used for whole-cell voltage clamp. Gigaohm seals were formed by momentarily applying negative pressure to the inside of the patch pipette. When recording from cell-attached and inside-out membrane patches, the pipette contained (in mM) $110 \mathrm{~K}$-gluconate, 40 $\mathrm{KCl}, 1 \mathrm{CaCl}_{2}, 2 \mathrm{MgCl}_{2}$, and 10 HEPES, and the bath contained 110 Na-gluconate, $40 \mathrm{NaCl}, 2 \mathrm{MgCl}_{2}, 1$ EGTA, and $10 \mathrm{HEPES}$. For experiments on outside-out membrane patches, the pipette contained (in $\mathrm{mM}$ ) $110 \mathrm{Na}$-gluconate, $40 \mathrm{NaCl}, 2 \mathrm{MgCl}_{2}, 1 \mathrm{EGTA}$, and $10 \mathrm{HEPES}$, and the bath contained (in $\mathrm{mm}$ ) $110 \mathrm{~K}$-gluconate, $40 \mathrm{KCl}, 1 \mathrm{CaCl}_{2}, 2 \mathrm{MgCl}_{2}$, and 10 HEPES. All pipette and bath solutions were buffered to a pH of 7.3 with either $\mathrm{KOH}$ or $\mathrm{NaOH}$, depending on the experiment. Other bath and pipette solutions are detailed in the text as needed. Quoted potentials are equal to the command voltages minus any offset voltages caused by junction potentials (usually $3-8 \mathrm{mV}$ ). Normal cellular convention is used to describe voltage with respect to ground, and inward current through open channcls is shown as downward deflections from the closed level bascline. Drugs and solutions of different ionic composition were applied by superfusion. Except where noted, all experiments were performed at room temperature.

Data acquisition and analysis. Single-channel data were stored on a VCR modified for FM recording (Vetter 420 VCR Format Data Recorder). Data were subsequently filtered at $1-2 \mathrm{kHz}(-3 \mathrm{~dB})$ using an eight-pole low-pass Bessel filter (Frequency Devices 902LPF), and digitized at $10 \mathrm{kHz}$ using an Everex Step 386/20 computer and a Tecmar Labmaster A/D board. The data were analyzed off line using either a program (SINGIBx) written by Dr. Peter Reinhart, which was based on the Indec Fastlab software library, or by a program (PAT, version 6.1) kindly supplied by John Dempster of the University of Strathclyde. For kinetic analysis of single-channel data, an automated $25-30 \%$ crossing threshold routine was used to collect $24,000-30,000$ channel transitions. Then, sections of the idealized record were compared by eye to the raw data to insure correct interpretation of the events. Binned data were exported to sIGMAPLOT (Jandel Co.), where curves were fit to amplitude and dwell time histograms using a Levenberg-Marquadt curve-fitting algorithm. Events lasting less than $0.5 \mathrm{msec}$, which were unlikely to be properly resolved, were excluded by discarding the first bin of the dwell time histograms and therefore did not contribute to the fitted curves.

Channel gating was characterized by bursting behavior in which the channel alternated between the fully open state, the substates and the fully closed state. $K_{N_{a}}$ channels occasionally remained closed for a long time before reopening (a 5-10 min closure was not unusual; see Results). We consider such long closures to reflect an additional state of the channel. This inactive state was entered only occasionally, and it contributed little to the total closed time histogram. Thus, closures longer than $1 \mathrm{sec}$ were not included in the kinetic analysis of the data, and closures longer than $2 \mathrm{sec}$ were not included in estimates of $P_{o}$. In many experiments, more than one $K_{\mathrm{N}}$ channel was actively gating in the membrane patch, in which case activity was counted as the number of channels $(N)$ multiplied by $P_{\sigma}$. Estimates of $N P_{o}$ included all data, as longer closures of individual channels could not be discerned because of the simultaneous gating of many channels.

Each experiment was repeated at least six times unless otherwise noted. Results are expressed as the sample mean \pm SD of $n$ observations.

\section{Results}

Our cultures contained predominantly two types of neurons as distinguished by their morphology. The first type was pyramidal shaped and had a single large neurite extending from each of its three corners. The second type was bipolar. The properties of these two neuronal populations have recently been described in detail by Trombley and Westbrook (1990), who suggest that the first type are mitral/tufted cells and the second are granule cells. Most of the experiments described here were performed on the larger pyramidal-shaped neurons, although some experiments used bipolar cells. $K_{N_{a}}$ channel activity was recorded from both cell types, and there was no obvious difference in the behavior of the channel between the two populations. 
Figure $1 . \quad \mathrm{K} \cdot$ channels activated by $\left[\mathrm{Na}^{+}\right]_{\text {. }}$ The record shows channel activity of an inside-out membrane patch excised from a cultured olfactory bulb neuron and bathed in different $\left[\mathrm{Na}^{+}\right]_{\text {. }}$. $V_{m}$ was $-40 \mathrm{mV} ;\left[\mathrm{K}^{+}\right]_{o} /\left[\mathrm{K}^{+}\right]_{i}$ equaled $150 / 0 \mathrm{~mm}$. Under these conditions, inward current through open channels is shown as downward deflections from the closed level. The solid line indicates the zero current level at which all channels are fully closed. The membrane patch contained at least eight $\mathrm{K}_{\mathrm{N} \text {, }}$ channels. Superimposed openings were common when $\left[\mathrm{Na}^{+}\right]$, equaled $60 \mathrm{~mm}(a)$. The channels were open less often when $\left[\mathrm{Na}^{+}\right]_{\text {e }}$ equaled $40 \mathrm{~mm}(b)$ and $20 \mathrm{~mm}$ (c). No channels were open in the absence of $\left[\mathrm{Na}^{+}\right]_{1}(d)$. Channel activity returned to near control levels upon reintroduction of $\left[\mathrm{Na}^{+}\right]$, (not shown). a

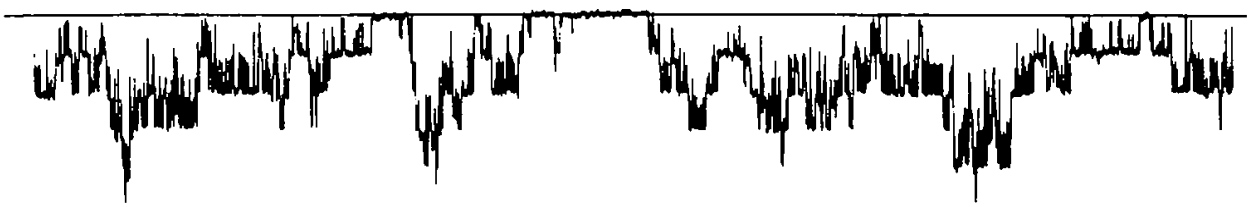

$\mathrm{b}$

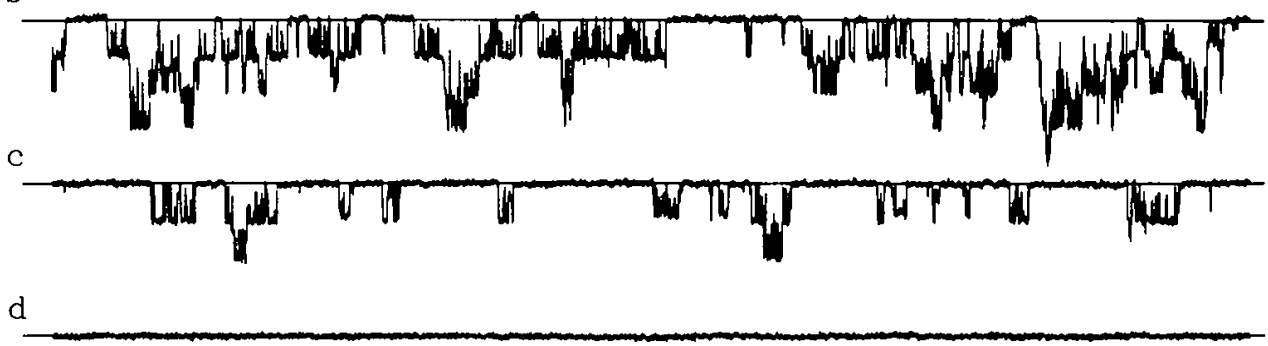

$16 \mathrm{pA}$
Several different classes of $\mathrm{K}^{+}$-selective channels were recorded in inside-out and outside-out patches of cultured olfactory bulb neurons. Two of these channel classes were distinguished by their selective activation by different cations. The first class required $\mathrm{Ca}^{2+}$, and, on the basis of data obtained in the presence of low $\left[\mathrm{Na}^{+}\right]$,/high $\left[\mathrm{Ca}^{2+}\right]$, solutions, was determined to be a member of the "maxi-K" $\mathrm{K}_{\mathrm{Ca}}$ channel family (Egan et al., 1990). The second class was active when $\left[\mathrm{Na}^{+}\right]_{i}$ was greater than about 10-20 $\mathrm{mm}$ and thus was classified as a $\mathrm{K}_{\mathrm{Na}}$ channel (Fig. 1). In a survey of 120 inside-out patches in which $\left[\mathrm{Na}^{+}\right]_{i}$ and $\left[\mathrm{Ca}^{2+}\right]_{i}$ exceeded $20 \mathrm{~mm}$ and $10 \mu \mathrm{M}$, respectively, $43 \%$ (52 of 120 ) of the patches had only $\mathrm{K}_{\mathrm{Na}}$ channels, $15 \%$ (18 of 120 )

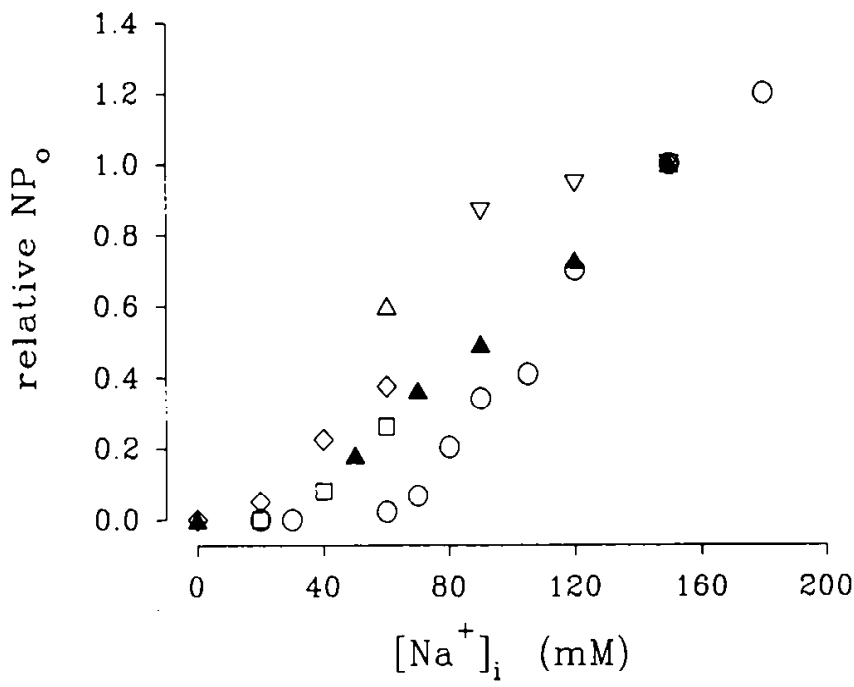

Figure 2. $\left[\mathrm{Na}^{+}\right]$, increases $\mathrm{K}_{\mathrm{Na}}$ channel activity in a dose-dependent manner. $N P_{0}$ was measured at many different $\left[\mathrm{Na}^{+}\right]$, levels for six multichannel inside-out membrane patches (separate symbols for each patch). The graph shows relative $N P_{o}$ plotted against $\left[\mathrm{Na}^{+}\right]_{i}$, where the relative $N P_{\text {o }}$ equaled the $N P_{0}$ measured at a given $\left[\mathrm{Na}^{+}\right]_{\text {l }}$ divided by the $N P_{0}$ measured at $150 \mathrm{~mm}\left[\mathrm{Na}^{+}\right] . V_{m}$ equaled $-40 \mathrm{mV}$. had only $\mathrm{K}_{\mathrm{Ca}}$ channels, and $32 \%$ (38 of 120 ) had both $\mathrm{K}_{\mathrm{Na}}$ and $K_{\text {Ca }}$ channels. Only a few patches $(12$ of $120,10 \%)$ had neither channel type. When a patch contained both types of cationactivated channels, $\mathrm{K}_{\mathrm{Na}}$ channels were isolated by chelating $\mathrm{Ca}^{2+}$, with EGTA $\left(\left[\mathrm{Ca}^{2+}\right]<10 \mathrm{nM}\right)$. Usually, membrane patches contained several active $K_{\mathrm{Na}}$ channels, although single-channel patches were observed. For example, in a survey of 90 patches containing $\mathrm{K}_{\mathrm{Na}}$ channels (150 $\mathrm{mM}\left[\mathrm{Na}^{+}\right]_{i} ; V_{m}=-40 \mathrm{mV}$ ), seven had single channels. We concluded that we had a single $K_{N_{a}}$ channel in a patch only when no single-channel current superpositions were seen when the $P_{v}$ was very high $(\geq 0.8)$.

\section{Some $\mathrm{K}^{+}$channels are $\left[\mathrm{Na}^{+}\right]_{\mathrm{i}}$ dependent}

We did not observe channel activity in on-cell patches of olfactory bulb neurons held at the resting $V_{m}$ under normal conditions. However, a common event upon excision of an insideout membrane patch into a $150 \mathrm{~mm} \mathrm{Na}{ }^{+} /$low $\mathrm{Ca}^{2+}$ solution was the immediate appearance of channel gating activity. The amount of channel activity was determined by $\left[\mathrm{Na}^{+}\right]_{i}$. The patch of Figure 1 contained at least eight $\mathrm{K}_{\mathrm{Na}}$ channels, all of which were actively gating at $150 \mathrm{mM}\left[\mathrm{Na}^{+}\right]_{i}$, and the current trace never had a period of zero channel activity with this high $\left[\mathrm{Na}^{+}\right]_{i}$ (not shown). When $\left[\mathrm{Na}^{+}\right]_{i}$ was decreased to $60 \mathrm{mM}$ by replacement with equimolar $\mathrm{K}^{+}$, the $P_{o}$ fell so that discreet openings and closings from a stable zero current baseline were seen (Fig. 1a). Channel gating decreased further in a graded manner as $\left[\mathrm{Na}^{+}\right]$, was lowered from 60 to $20 \mathrm{~mm}$ (Fig. $1 a-c$ ), and no channel openings were apparent in the absence of $\mathrm{Na}^{+}$, (Fig. 1d). Channel gating recovered when $\mathrm{Na}^{+}$, was again introduced (not shown). $\mathrm{Li}^{+}{ }_{i}(60-150 \mathrm{~mm})$, an effective substitute for $\mathrm{Na}^{+}$, in many physiological processes, did not open $\mathrm{K}_{\mathrm{Na}}$ channels when it replaced $\mathrm{Na}^{+}$as the major ion bathing the internal surface of inside-out membrane patches. As stated above, many patches contained both $\mathrm{K}_{\mathrm{Na}}$ and $\mathrm{K}_{\mathrm{Ca}}$ channcls, which differed in mean conductance, gating behavior, and the presence of substates (see below). However, in patches containing only $\mathrm{K}_{\mathrm{Ne}}$ channels, changes in $\left[\mathrm{Ca}^{2+}\right]_{i}$ did not affect $\mathrm{K}_{\mathrm{Na}}$ channel activity. $\mathrm{K}^{+}{ }_{i}$ (up to $150 \mathrm{~mm}$ ) 
a

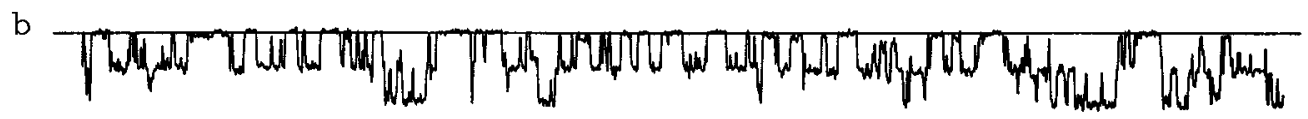

c

d

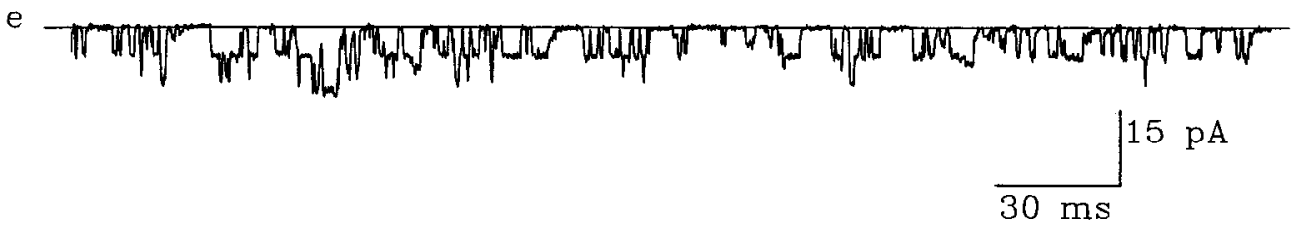

Figure 3. $\mathrm{K}_{\mathrm{Na}}$ channels recorded from on-cell patches: records from a cell-attached patch of cultured olfactory bulb neuronal membrane. The recording pipette contained $150 \mathrm{~mm}\left[\mathrm{~K}^{+}\right]$, and the applied pipette voltage was $40 \mathrm{mV}$. $a$, The cell was bathed initially in a solution containing 150 $\mathrm{mM} \mathrm{Na}$. Under these conditions, no channel activity was observed. $b$, Addition of $100 \mu \mathrm{M}$ veratridine to the bath solution resulted in the onset of channel gating. At least two channels were present in the membrane patch. $c$, A few minutes after $150 \mathrm{~mm}\left[\mathrm{~K}^{+}\right]_{o}$ replaced $150 \mathrm{~mm}\left[\mathrm{Na}^{+}\right]_{o}$, channel gating ceased even in the continued presence of veratridine. Channel gating recovered after changing back to a $150 \mathrm{~mm}\left[\mathrm{Na}^{+}\right]_{o}$ plus veratridine solution (not shown). $d$, Addition of TTX (100 nM) also prevented channel gating in the presence of $150 \mathrm{~mm}^{2}\left[\mathrm{Na}^{+}\right]_{i}$, presumably by preventing $\mathrm{Na}^{+}$influx through voltage-activated $\mathrm{Na}^{+}$channels kept open by veratridine $(100 \mu \mathrm{M})$. $e$, Patch excision into a $150 \mathrm{mM}\left[\mathrm{Na}^{+}\right]_{i}$ solution restores channel activity even when TTX is present.

and $\mathrm{Mg}^{2+}{ }_{i}$ (up to $10 \mathrm{mM}$ ) also were ineffective in opening these channels.

The initial $\left[\mathrm{Na}^{+}\right]_{i}$ sensitivity of our sample group of $\mathrm{K}_{\mathrm{Na}}$ channels varied from cell to cell as determined by measuring the $P_{o}$ (or the $N P_{o}$ ) at a $V_{m}$ of -40 to $-60 \mathrm{mV}$ immediately after excising into $150 \mathrm{~mm}\left[\mathrm{Na}^{+}\right]_{i}$. The variability is connected, we believe, to the phenomenon of rundown (see below). Many $\mathrm{K}_{\mathrm{Na}}$ channels had very high $P_{o}$ values in $150 \mathrm{~mm}\left[\mathrm{Na}^{+}\right]_{i}\left(P_{o}\right.$ near 0.8 , measured at $-40 \mathrm{mV}$ ), and the activities of these channels were not further increased by raising $\left[\mathrm{Na}^{+}\right]_{i}$. However, channels that were less sensitive to $150 \mathrm{~mm}\left[\mathrm{Na}^{+}\right]_{i}\left(P_{o}<0.8\right)$ did respond to increases in $\left[\mathrm{Na}^{+}\right]_{i}$. To determine the average $\left[\mathrm{Na}^{+}\right]_{i}$ versus $N P_{o}$ relationship, we constructed $\left[\mathrm{Na}^{+}\right]_{i}$ versus $N P_{o}$ curves for channel activity in six multiple-channel patches (Fig. 2). Dose-response curves of activity from multiple-channel patches showed that $\left[\mathrm{Na}^{+}\right]_{i}$ continued to increase $N P_{o}$ even at very high $\left[\mathrm{Na}^{+}\right]_{i}$. For example, in one patch (open circles, Fig. 2) activity was dose dependent over the entire range of $\left[\mathrm{Na}^{+}\right]_{i}$ tested, and even at the highest $\left[\mathrm{Na}^{+}\right]_{i}(180 \mathrm{~mm})$, the curve did not plateau. The absence of saturation of the $\left[\mathrm{Na}^{+}\right]_{i}$ versus $N P_{o}$ curve in this range of $\left[\mathrm{Na}^{+}\right]_{i}$ has also been reported for $\mathrm{K}_{\mathrm{Na}}$ channels in multiplechannel patches of chick cultured brainstem neurons (Dryer et al., 1989).

As stated above, no channel activity was normally seen in recordings from on-cell membrane patches (Fig. $3 a$ ). However, it was possible to activate $\mathrm{K}_{\mathrm{Na}}$ channels in cell-attached patches when $\left[\mathrm{Na}^{+}\right]_{i}$ was raised with veratridine. This drug prevents inactivation of voltage-dependent $\mathrm{Na}^{+}$channels, thereby allowing $\mathrm{Na}^{+}$to leak into the cell. Superfusion of veratridine (1-100 $\mu \mathrm{M}$ ) resulted in the appearance of channels resembling $\mathrm{K}_{\mathrm{Na}}$ channels with respect to the presence of multiple substates (see below) and an absolute dependence on $\left[\mathrm{Na}^{+}\right]_{i} \cdot \mathrm{K}_{\mathrm{Na}}$ channels began gating 1-5 min after superfusion of veratridine (Fig. $3 b$ ). Interestingly, the $\mathrm{K}_{\mathrm{Na}}$ single-channel current amplitude increased during the first few minutes of the effect of veratridine. This increase in current amplitude most likely resulted from an increased driving force for current flow through these $\mathrm{K}^{+}$-selective channels (see below), suggesting that veratridine hyperpolarized these cells by indirectly opening $\mathrm{K}_{\mathrm{Na}}$ channels. $\mathrm{K}_{\mathrm{Na}}$ channels recorded from on-cell patches under these conditions routinely continued to gate in a regular manner for as long as the patch was held (up to $90 \mathrm{~min}$ ). Further, in the continued presence of veratridine, $\left[\mathrm{Na}^{+}\right]_{i}$ was manipulated by changing $\left[\mathrm{Na}^{+}\right]_{o}$ or by preventing $\mathrm{Na}^{+}$influx through voltage-gated $\mathrm{Na}^{+}$channels with TTX $(0.1-$ $10 \mu \mathrm{M})$. Channel activity ceased when $\left[\mathrm{Na}^{+}\right]_{o}$ was decreased from 150 to $0 \mathrm{~mm}$ (Fig. $3 c$ ), or when TTX (100 nM) was added in the presence of normal $\left[\mathrm{Na}^{+}\right]_{o}$ (Fig. $3 d$ ). TTX had no direct effect on $\mathrm{K}_{\mathrm{Na}}$ channels (Fig. $3 e$; see also below), and in any event in these experiments it was applied to the outside of the patch electrode. Likewise, channel activity gradually disappeared after washout of veratridine if the external solution contained at least $5 \mathrm{mM}\left[\mathrm{K}^{+}\right]_{o}$, but not in the absence of $\mathrm{K}^{+}$, suggesting that an active $\mathrm{Na}^{+} / \mathrm{K}^{+}$pump is necessary to lower $\left[\mathrm{Na}^{+}\right]_{i}$ following washout of veratridine.

\section{Conductance and ion selectivity}

Inside-out and outside-out membrane patches were used to determine the conductance and selectivity of the fully open channel. Using symmetrical $150 \mathrm{mM}\left[\mathrm{K}^{+}\right]$conditions in an insideout patch where $\left[\mathrm{Na}^{+}\right]_{i}$ was $60 \mathrm{mM}$, the $I-V$ curve was linear and the slope conductance measured $161 \mathrm{pS}$ over the potential range of -10 to $-100 \mathrm{mV}$ (Fig. 4). $E_{\text {rev }}$ was $0 \mathrm{mV}$, equal to the predicted value of the $\mathrm{K}^{+}$equilibrium potential, even in the presence of these high levels of $\left[\mathrm{Na}^{+}\right]_{i}$, suggesting that the channel was more permeable to $\mathrm{K}^{+}$than to $\mathrm{Na}^{+}$. In other experiments using symmetrical $150 \mathrm{~mm}\left[\mathrm{~K}^{+}\right]$and $60-120 \mathrm{mM}\left[\mathrm{Na}^{+}\right]_{i}$, the 


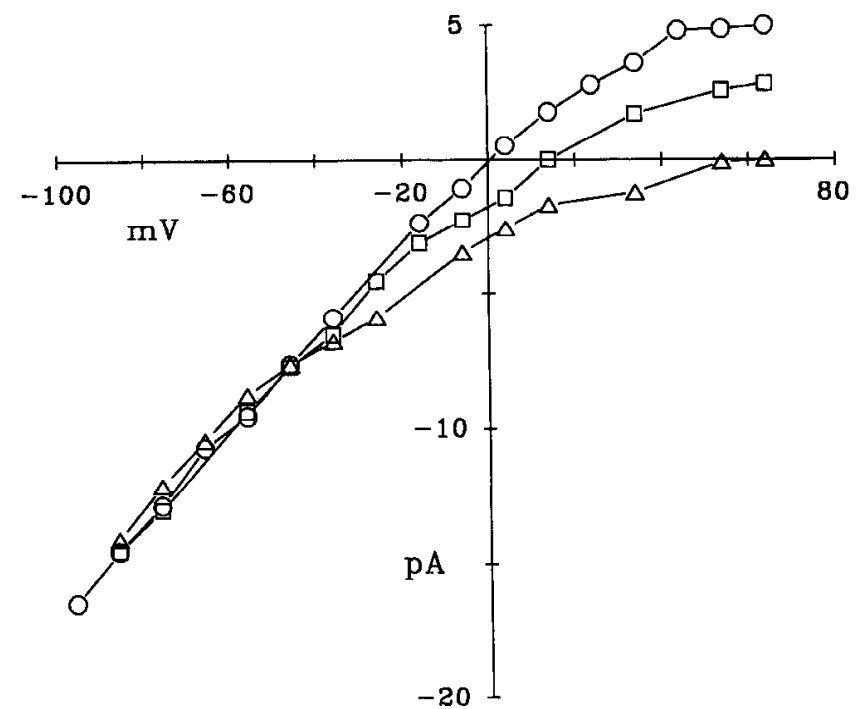

Figure 4. $\quad \mathrm{K}_{\mathrm{Na}}$ channels are $\mathrm{K}^{+}$selective: $I-V$ curves for $\mathrm{K}_{\mathrm{Na}}$ channels of an inside-out membrane patch bathed in different $\left[\mathrm{K}^{+}\right]_{i}$ and $\left[\mathrm{Na}^{+}\right]_{i}$. In all three cases, $\left[\mathrm{K}^{+}\right]_{o}$ equaled $150 \mathrm{~mm}$. Top curve $(\mathrm{O}),\left[\mathrm{K}^{+}\right]_{i}$ equaled $150 \mathrm{~mm}$ and $\left[\mathrm{Na}^{+}\right]_{i}$ equaled $60 \mathrm{~mm}$. We did not correct for the osmotic imbalance caused by $\mathrm{Na}^{+}$. Middle curve $(\square),\left[\mathrm{K}^{+}\right]_{i}$ equaled $60 \mathrm{~mm}$ and $\left[\mathrm{Na}^{+}\right]_{i}$ equaled $90 \mathrm{~mm}$. Lower curve $(\Delta),\left[\mathrm{K}^{+}\right]_{i}$ equaled $0 \mathrm{~mm}$ and $\left[\mathrm{Na}^{+}\right]_{i}$ equaled $150 \mathrm{~mm}$. Slope conductance, measured from the linear portion of the $I-V$ curve at negative $V_{m}$ under symmetrical $150 \mathrm{mM}\left[\mathrm{K}^{+}\right]$conditions (O), was $161 \mathrm{pS}$.

average slope conductance at negative $V_{m}$ was $172 \pm 8 \mathrm{pS}(n=$ 8 ) and the average $E_{\text {rev }}$ was $0 \pm 2 \mathrm{mV}(n=14)$. At positive $V_{m}$, the channel showed inward rectification.

Selectivity was further measured by varying $\left[\mathrm{Na}^{+}\right]_{i}$ and $\left[\mathrm{K}^{+}\right]_{i}$ (Fig. 4). No outward current could be measured when $\mathrm{Na}^{+}$, completely replaced $\mathrm{K}^{+}{ }_{i}$. When $\left[\mathrm{K}^{+}\right]_{o} /\left[\mathrm{K}^{+}\right]_{i}$ equaled $150 / 60$ and $\left[\mathrm{Na}^{+}\right]_{i}$ equaled $90 \mathrm{~mm}$, the average $E_{\text {rev }}$ was $18.9 \pm 2.9 \mathrm{mV}$, which is close to the value of $23 \mathrm{mV}$ predicted by the Nernst equation for a $\mathrm{K}^{+}$-selective pore, and the average slope conductance was $149.3 \pm 9.2 \mathrm{pS}(n=4)$. The $I-V$ curves were unaffected by changes in $\left[\mathrm{Cl}^{-}\right]_{i}$ and $\left[\mathrm{Cl}^{-}\right]_{0}$.

The degree of inward rectification seen at positive $V_{m}$ depended on $\left[\mathrm{Na}^{+}\right]_{i}$ (Fig. 5). This was shown by varying $\left[\mathrm{Na}^{+}\right]_{i}$ between 30 and $120 \mathrm{~mm}$ while keeping $\left[\mathrm{K}^{+}\right]_{i}$ and $\left[\mathrm{K}^{+}\right]_{o}$ constant at $150 \mathrm{~mm}$ each. Inward rectification increased as $\left[\mathrm{Na}^{+}\right]_{i}$ increased, suggesting that $\left[\mathrm{Na}^{+}\right]_{i}$ can block outward flow of $\mathrm{K}^{+}$ through the open channel. No increase in open-channel noise was evident in the limited bandwidth used in these experiments, and $\mathrm{Na}^{+}$may therefore be a very fast blocker of $\mathrm{K}_{\mathrm{Na}}$ channels. Similar evidence of fast $\mathrm{Na}^{+}$block of $\mathrm{K}_{\mathrm{Na}}$ channels of heart has recently been presented by Wang et al. (1991). Although, as stated above, $\mathrm{Li}^{+}$failed to activate olfactory bulb $\mathrm{K}_{\mathrm{Na}}$ channels, it shared with $\mathrm{Na}^{+}$the ability to block $\mathrm{K}_{\mathrm{Na}}$ channels (data not shown). $\mathrm{Ca}^{2+}$ had no effect on the current-voltage relationship.

\section{$K_{N a}$ channels are voltage dependent}

$P_{o}$ was measured at different $V_{m}$ to determine the effect of voltage on channel activity. The experimental protocol was as follows. Inside-out membrane patches were held at different $V_{m}$ levels in a staggered order (e.g., $-80,+80,-40,+40 \mathrm{mV})$ to avoid confusing a change in the $P_{o}$ caused by rundown $\left(P_{o}\right.$ vs. time; see below) with a change resulting from the effect of voltage $\left(P_{o}\right.$ vs. $\left.V_{m}\right) \cdot\left[\mathrm{K}^{+}\right]_{o}$ and $\left[\mathrm{K}^{+}\right]_{i}$ equaled $150 \mathrm{~mm}$. $P_{o}$, measured at -80 $\mathrm{mV}$, was kept low (less than 0.6$)$ by changing $\left[\mathrm{Na}^{+}\right]_{i}(30-120$

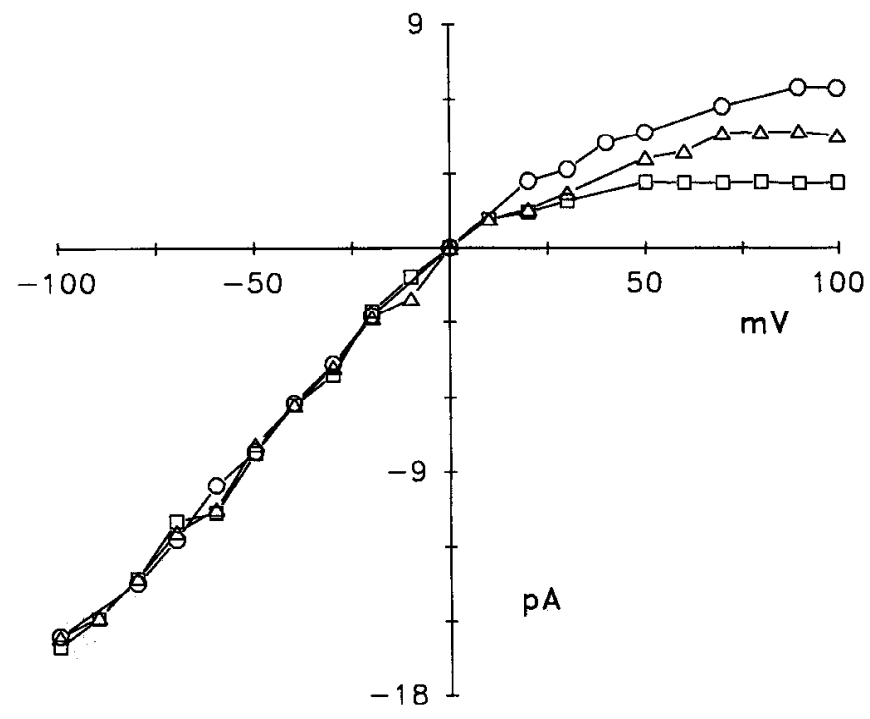

Figure 5. $\left[\mathrm{Na}^{+}\right]_{i}$ increases inward rectification. $\mathrm{K}_{\mathrm{Na}}$ single-channel current was measured in inside-out membrane patches. $\left[\mathrm{K}^{+}\right]_{o}$ and $\left[\mathrm{K}^{+}\right]_{i}$ equaled $150 \mathrm{~mm}$ and $\left[\mathrm{Na}^{+}\right]_{i}$ equaled $30(\mathrm{O}), 60(\triangle)$, and $120 \mathrm{~mm}(\square)$. At negative voltages, $I$ - $V$ curves were linear and had slope conductances of about $145 \mathrm{pS}$. At positive potentials, $\left[\mathrm{Na}^{+}\right]_{i}$ blocked the outward flow of $\mathrm{K}^{+}$.

mm). Under these conditions, the $P_{o}$ varied as a function of $V_{m}$, increasing with depolarization and decreasing with hyperpolarization. This effect of voltage was most pronounced at low initial $P_{o}$ (measured at $-80 \mathrm{mV}$ ). For example, in one experiment changing $V_{m}$ from $-80 \mathrm{mV}$ to $-40 \mathrm{mV}$ resulted in a threefold change in the $P_{o}$ (change from 0.06 to 0.18 ). However, at higher initial $P_{o}$ values, changing $V_{m}$ had less of an effect, and at very high initial $P_{o}$ values (near 0.8 at $-80 \mathrm{mV}$ ), no voltage dependence was observed.

\section{Gating kinetics}

Gating behavior was characterized by long periods of bursting activity in which the channel rapidly alternated between a fully open state, multiple subconductance states (see below), and a fully closed state (Fig. $6 a$ ). Between groups of bursts, the channel occasionally entered an inactive state where it remained closed for several hundreds of milliseconds to minutes, after which it returned to its bursting mode for several minutes before falling quiet again. This pattern of occasional long quiet periods separating groups of bursts has also been reported for the $\mathrm{K}_{\mathrm{Na}}$ channel gating of mammalian heart (Luk and Carmeliet, 1990). As mentioned above, most membrane patches contained many $\mathrm{K}_{\mathrm{Na}}$ channels. Also, most $\mathrm{K}_{\mathrm{Na}}$ channels showed a gradual decrease in the $P_{o}$ with time after excision (i.e., rundown; see below). These two facts confounded analysis of $\mathrm{K}_{\mathrm{Na}}$ channel transition rate constants. However, in a few patches, single $\mathrm{K}_{\mathrm{Na}}$ channels gated for the entire period beginning immediately after excision into $150 \mathrm{~mm}\left[\mathrm{Na}^{+}\right]$and lasting until the seal deteriorated (see, e.g., Fig. 13); such patches were used for kinetic analysis.

Kinetic rate constants were determined from data collected during extended periods of stable $P_{o}$. Two minutes of data were used to construct dwell time histograms of all the open times and for closed times shorter than $1 \mathrm{sec}$. Open and closed time histograms for two $\mathrm{K}_{\mathrm{Na}}$ channels with the $P_{o}$ equal to 0.55 and 0.85 are shown in Figures $6 b$ and 7 . The open time histograms for the two channels were almost identical; each was fit well by 
a

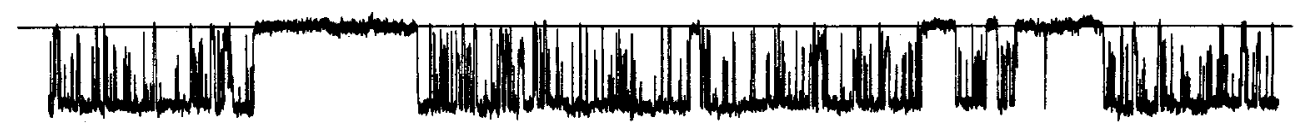

$b$

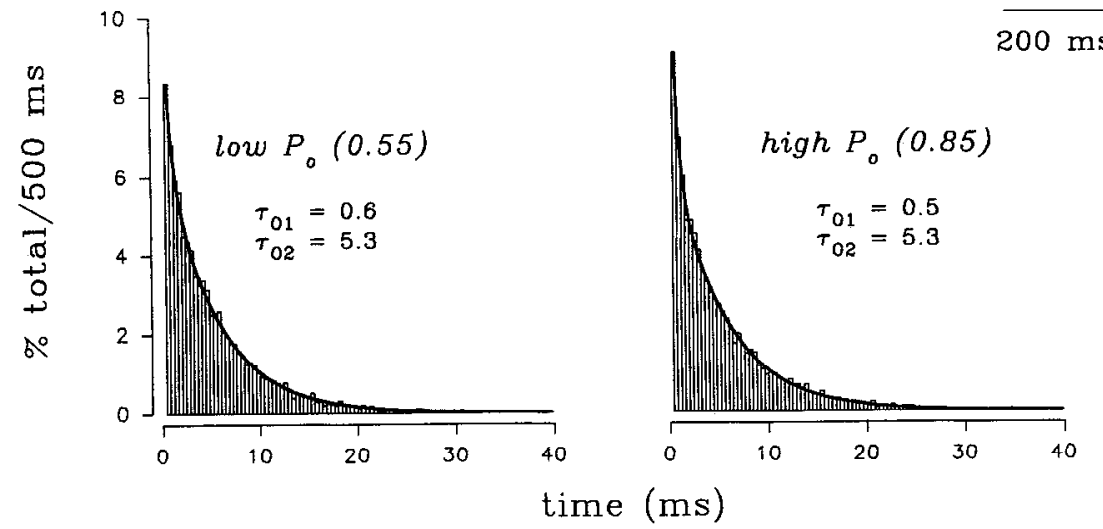

Figure 6. Open time histograms. a, A $\mathbf{K}_{\mathrm{Na}}$ channel showed bursts of openings and closures punctuated by longer closures. This channel occasionally remained closed for up to $1 \mathrm{~min}$ (not shown). The solid line indicates the zero current level. $V_{m}$ was $-70 \mathrm{mV}$. $\left[\mathrm{K}^{+}\right]_{o}$ ' $\left[\mathrm{K}^{+}\right]_{i}$ equaled $150 / 0 \mathrm{~mm}$, and $\left[\mathrm{Na}^{+}\right]_{i}$ equaled 150 mм. $b$, Open time histograms of data of two different channels differing in $P_{o}$. Open times were measured for a $2 \mathrm{~min}$ stretch of data. The data of each histogram were fit well by the sum of two exponential functions. Left histogram, Data from experiment pictured in $a$. The $P_{o}$ equaled 0.55. $\tau_{o 1}$ was $0.6 \mathrm{msec}$ and $\tau_{O 2}$ was $5.3 \mathrm{msec}$. Right histogram, $V_{m}$ was $-80 \mathrm{mV}$. $\left[\mathrm{K}^{+}\right]_{d} /\left[\mathrm{K}^{+}\right]_{i}$ equaled $150 / 0 \mathrm{~mm}$ and $\left[\mathrm{Na}^{+}\right]_{i}$ equaled $150 \mathrm{~mm}$. The $P_{0}$ equaled 0.85 . $\tau_{o 1}$ and $\tau_{o 2}$ equaled 0.5 and $5.3 \mathrm{msec}$, respectively. the sum of two exponentials with $\tau_{o 1}$ equal to about $0.6 \mathrm{msec}$ and $\tau_{o 2}$ equal to about $5.3 \mathrm{msec}$ (Fig. $6 \mathrm{~b}$ ). The closed time histograms differed (Fig. 7). For both channels, about $95 \%$ of the closures lasted less than $15 \mathrm{msec}$, and the closed time histograms of data in this range were roughly equivalent for the two experiments; each was described by the sum of two exponential functions (Fig. 7, upper panels). The biggest difference in gating patterns involved longer closures. This is shown in the lower panels of Figure 7, where closures in the $15-1000 \mathrm{msec}$ range are tabulated. These data from the less active channel were fit by two additional exponential functions where $\tau_{\mathrm{C} 3}$ and $\tau_{C 4}$ equaled 10.5 and $142 \mathrm{msec}$, respectively (Fig. 7, bottom left panel). We did not measure $\tau_{C 3}$ and $\tau_{C 4}$ for the more active channel because, although we collected about 25,000 total transitions, longer closures occurred infrequently, and we therefore could not reliably assign rate constants to these data. Even for the less active channel, $\tau_{\mathrm{C} 3}$ and $\tau_{\mathrm{C} 4}$ were derived from a relatively small number of events and should therefore be considered to estimate the true values of these parameters. Table 1 shows the kinetic time constants for six different channels. These data
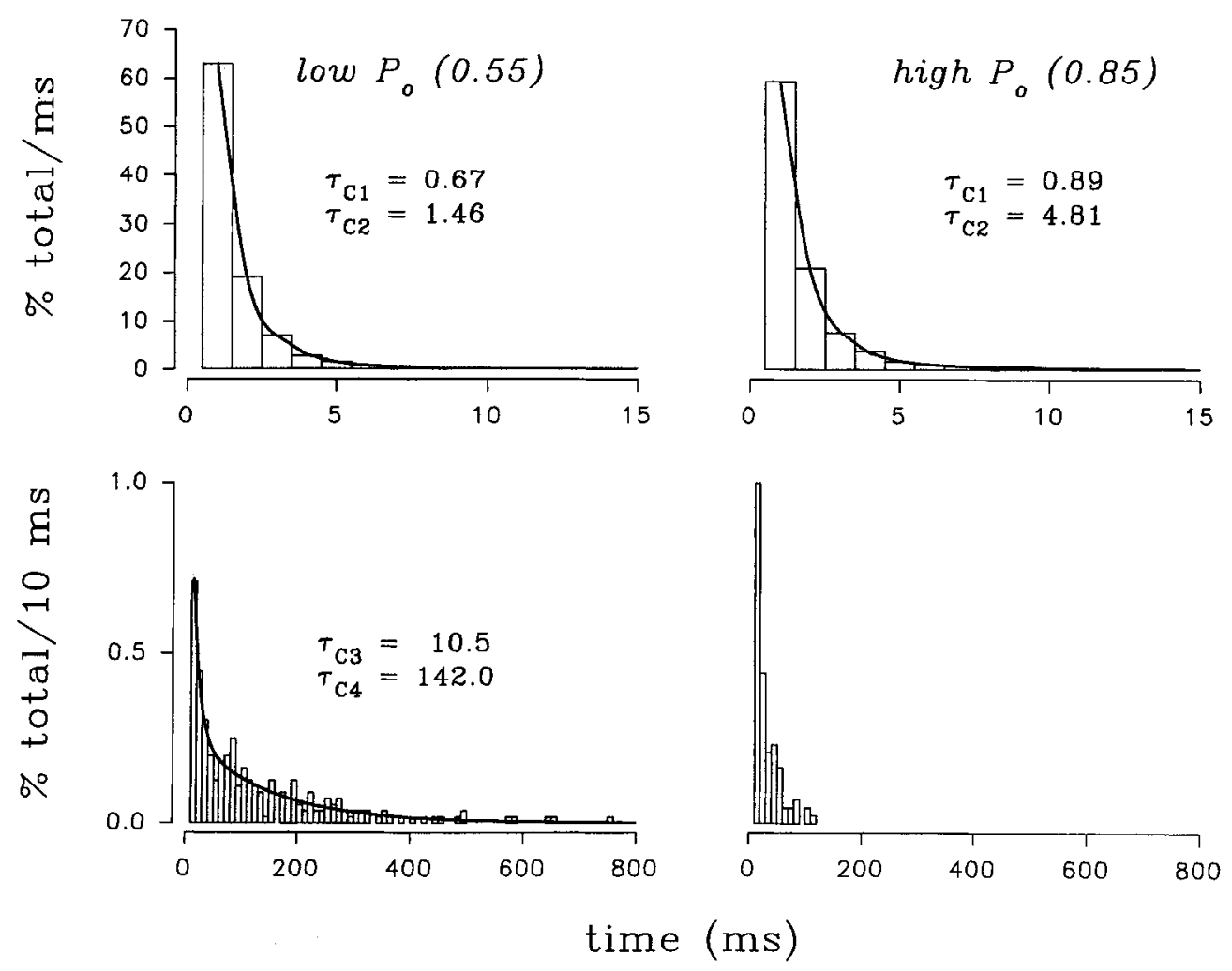

Figure 7. Closed time histograms: data from the same experiments as in Figure $6 b$. Two closed time histograms were generated for each experiment. Curves are the best fit to the data determined by an iterative curve-fitting program. Upper panels tabulate closures in the 0.5-15 msec range. Top left panel, The $P_{o}$ equaled $0.55 . \tau_{C 1}$ and $\tau_{C 2}$ equaled 0.7 and $1.5 \mathrm{msec}$, respectively. Top right panel, The $P_{n}$ equaled 0.85. $\tau_{C 1}$ and $\tau_{C 2}$ equaled 0.9 and $4.8 \mathrm{msec}$, respectively. Lower panels contain data in the 15$1000 \mathrm{msec}$ range. Bottom left panel, same experiment as top left panel. $\tau_{C 3}$ equaled $10.5 \mathrm{msec}$ and $\tau_{C 4}$ equaled 142 msec. Bottom right panel, Same experiment as top right panel. The histogram shows that few closures occur with durations in this time range in channels of high $P_{o}$. 

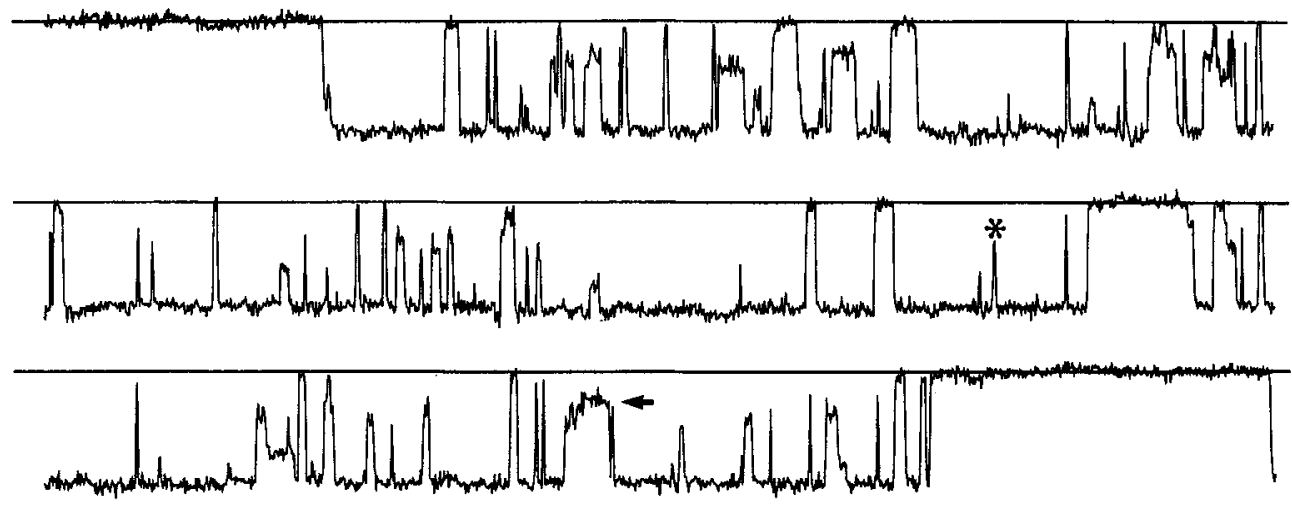

Figure 8. $\quad \mathrm{K}_{\mathrm{Na}}$ channel current substates. Data are taken from an insideout patch containing only a single $\mathrm{K}_{\mathrm{Na}}$ channel. $V_{m}$ was $-70 \mathrm{mV},\left[\mathrm{K}^{+}\right]_{\rho} /\left[\mathrm{K}^{+}\right]_{i}$ equaled $150 / 0$, and $\left[\mathrm{Na}^{+}\right]_{i}$ was $150 \mathrm{~mm}$. Inward currents typical of the open channel under these conditions are seen as downward deflections from the closed level (solid line). The arrows depict different substate levels, and the asterisks apparent substates that are not well resolved at our filter cutoff frequency (see Results).

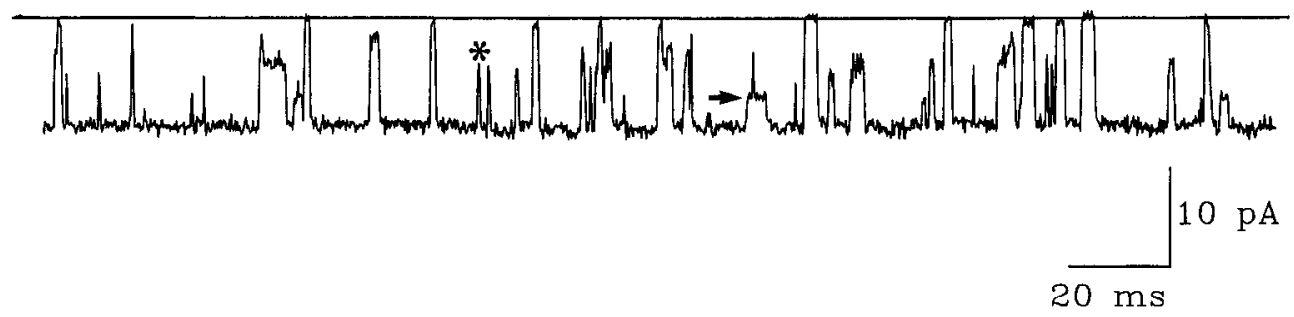

emphasize that the open times are remarkably constant from one channel to another regardless of the $P_{o}$, and only the closed times differ.

\section{Substates}

A distinguishing characteristic of the $\mathrm{K}_{\mathrm{Na}}$ channel was the presence of substates (Fig. 8; see also Figs. 10-12). These substates were seen as partial openings or partial closures during the burst interval. Within a burst a substate was entered from either the fully open or fully closed states, or from a different substate level. However, partial openings from the interburst fully closed state were rarely seen. Figure $9 a$ shows the all-points current amplitude histogram taken from an inside-out membrane patch containing a single $\mathrm{K}_{\mathrm{Na}}$ channel exposed to $150 \mathrm{mM}\left[\mathrm{Na}^{+}\right]_{i}$ and held at $-70 \mathrm{mV}$. The three data points at the beginning and end of each opening and closing were excluded from the raw data to prevent transition slurring of the binned data. $\left[\mathrm{K}^{+}\right]_{o} /$ $\left[\mathrm{K}^{+}\right]_{i}$ equaled $150 / 0$, and the single-channel conductance measured under these conditions was $175 \mathrm{pS}$. The histogram showed two clear peaks at about 0 and $12.25 \mathrm{pA}$, representing the fully closed and fully open states, respectively, each of which was fit well by a single Gaussian function. Between these two clear peaks were additional current amplitude points caused by the occurrence of multiple substates.

To estimate the number and relative size of the substates, idealized current amplitude data, corresponding to substate levels determined from the threshold crossing routine described in Materials and Methods, were tabulated and binned into a histogram (Fig. 9b). This histogram excluded data belonging to the fully opened or fully closed states, and included most of the substate amplitude data. Substate current amplitude histograms were not fit well by a single Gaussian function, suggesting the presence of at least two substates. Fitting the data with two Gaussian functions gave substate current amplitudes that measured about $41 \%$ and $57 \%$ of the fully open channel amplitude. Visual inspection of the raw data confirms the presence of multiple substates (arrows, Fig. 8). In five experiments analyzed in this manner, substates averaged $39 \pm 6 \%$ and $62 \pm 12 \%$ of the fully open channel amplitude. However, from the raw data we were able to identify more than two substates (see Fig. 8). In addition, the $2 \mathrm{kHz}$ cutoff frequency used in these experiments may have resulted in our failure to record accurately the full amplitude of some substate levels (asterisks, Fig. 8). Because of this uncertainty, and because the channel spent relatively little

Table 1. Transition rate constants for six $K_{\mathrm{Na}}$ channels

\begin{tabular}{llllllllr}
$\begin{array}{l}\text { Experi- } \\
\text { ment }\end{array}$ & $V_{m}$ & $P_{o}$ & $\tau_{O_{1}}$ & $\tau_{O_{2}}$ & $\tau_{C_{1}}$ & $\tau_{C_{2}}$ & $\tau_{C_{3}}$ & \multicolumn{1}{c}{$\tau_{C_{4}}$} \\
\hline 1 & -40 & 0.48 & $1.21(19)$ & $5.13(81)$ & 0.89 & 1.42 & 20.03 & 70.86 \\
2 & -70 & 0.55 & $0.64(44)$ & $5.27(56)$ & 0.67 & 1.46 & 10.04 & 142.00 \\
3 & -60 & 0.59 & $0.97(10)$ & $5.80(90)$ & 0.79 & 3.35 & 28.12 & 45.50 \\
4 & -60 & 0.81 & $0.85(38)$ & $6.82(62)$ & 0.70 & 3.77 & - & - \\
5 & -80 & 0.85 & $0.51(40)$ & $5.33(60)$ & 0.90 & 4.82 & - & - \\
6 & -80 & 0.89 & $1.23(31)$ & $7.08(69)$ & 0.89 & 4.21 & - & - \\
\hline
\end{tabular}

$V_{m}$ values are given in $\mathrm{mV} ; \tau$ values are given in msec. The numbers in parentheses are the percent weight of each $\tau_{o}$ Because $\tau_{C_{1}}$ and $\tau_{C_{2}}$, and $\tau_{C_{3}}$ and $\tau_{C_{4}}$ are estimated from different histograms, we could not accurately measure the

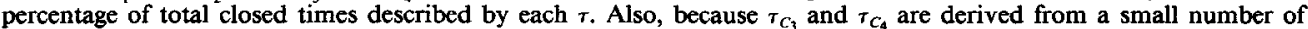
closures, curve fits estimate the real values of $\tau_{C_{3}}$ and $\tau_{C_{4}}$. 
a

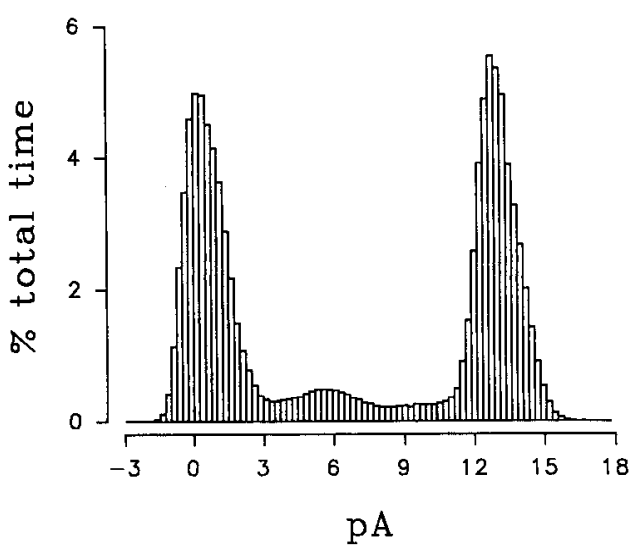

b substates

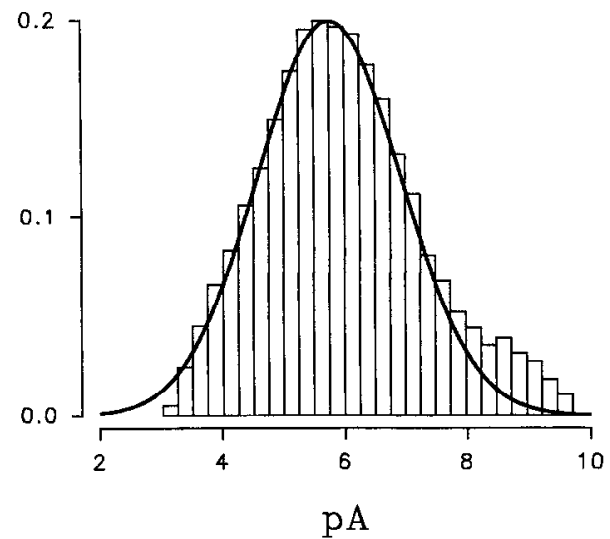

Figure 9. Amplitude histograms. Current amplitude histograms were constructed for data from the experiment pictured in Figure 8. a, Binned data of about 24,000 transitions. The all-points histogram showed two prominent peaks centered at 0 and $12.25 \mathrm{pA}$, and a small broad peak at about $5 \mathrm{pA}$. $b$, The histogram of the substate current amplitudes was obtained from idealized current records to avoid complications due to baseline and open channel noise. It was not fit well by a single Gaussian function (smooth line), suggesting that at least two substate levels were present. time in the multiple substate levels, we did not attempt to characterize the absolute number of substates.

The effect of $\left[\mathrm{Na}^{+}\right]_{i}$ on substate levels was tested for a $\mathrm{K}_{\mathrm{Na}}$ channel in an inside-out patch held at $-60 \mathrm{mV} .\left[\mathrm{K}^{+}\right]$, and $\left[\mathrm{K}^{+}\right]_{0}$ were kept constant at $150 \mathrm{~mm}$ each, and $\left[\mathrm{Na}^{+}\right]_{i}$ was changed to $60,90,120$, and $150 \mathrm{~mm}$. $\left[\mathrm{Na}^{+}\right]_{i}$ had no effect on either the relative amplitude or the relative occurrence of the two most prominent substate levels.

\section{Pharmacology}

$\mathrm{K}^{+}$channcls can be classified according to susceptibility to specific blockers. We tested some of these blockers on $\mathrm{K}_{\mathrm{Na}}$ channels. $d$-Tubocurarine ( $d$-TC) reduces the $P_{o}$ of $\mathrm{K}_{\mathrm{Ca}}$ channels (Smart, 1987). We found that this drug also decreases the $P_{o}$ of $\mathrm{K}_{\mathrm{Na}}$ channels, but at $10 \times$ higher concentrations than those needed for $\mathrm{K}_{\mathrm{Ca}}$ channels. Internal application of $d-\mathrm{TC}(10-100 \mu \mathrm{M})$ reduced the $P_{o}$ of $\mathrm{K}_{\mathrm{Na}}$ channels by changing the mean open and closed times without changing the single-channel conductance. Figure 10 shows an example of the effect of $50 \mu \mathrm{M} d$-TC applied to the internal membrane surface of an inside-out patch containing a single $\mathrm{K}_{\mathrm{Na}}$ channel. In the absence of drug, the channel was open about $50 \%$ of the time, and the mean open and closed times were 4.8 and $5.8 \mathrm{msec}$, respectively. In the presence of $d$-TC, the $P_{o}$ fell to 0.06 , the mean open time decreased to 1.9 msec, and the mean closed time increased to $26.3 \mathrm{msec}$. Application of $d$-TC to the external surface of the membrane had no effect in the concentration range tested here.

The piperidine $\mathrm{R} 56865$ has been reported to block the $\mathrm{K}_{\mathrm{Na}}$ channel of heart muscle (Luk and Carmeliet, 1990). In olfactory bulb neurons, $\mathrm{R} 56865(2.5 \mu \mathrm{M} ; n=3)$ acted like $d$-TC to reduce the $P_{o}$ of $\mathrm{K}_{\mathrm{Na}}$ channels when applied to the internal membrane surface (Fig. 11), as did the related compound R58735 (sabeluzole; $2.5 \mu \mathrm{M} ; n=2$ ). Similar concentrations of both piperidines also decreased the $P_{o}$ of $\mathrm{K}_{\mathrm{Ca}}$ channels in cultured olfactory bulb neurons, although another unidentified type of $\mathrm{K}^{+}$channel was not affected (T. M. Egan and J. Kupper, unpublished observations). R56865 and R58735 therefore should not be considered selective blockers of $\mathrm{K}_{\mathrm{Na}}$ channels. Neither the voltage-activated a
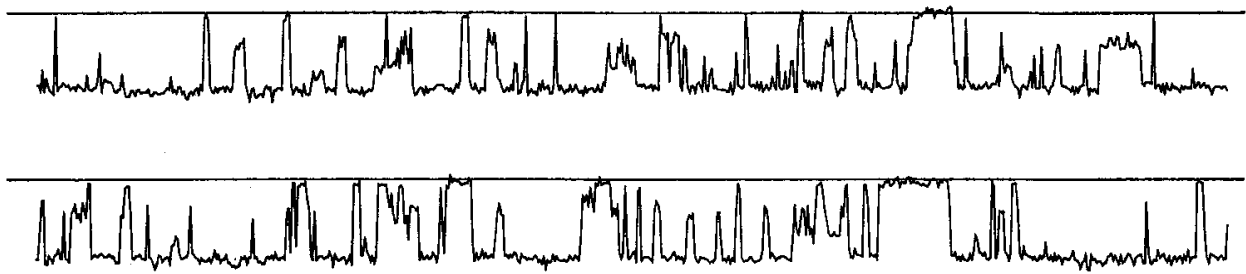

$\mathrm{b}$
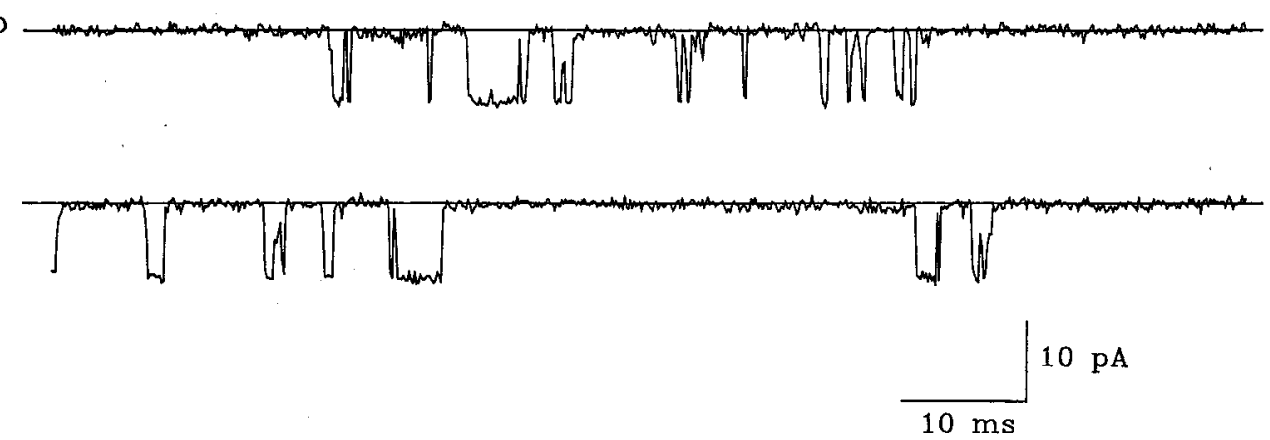

Figure 10. $\quad d$-TC blocks $\mathrm{K}_{\mathrm{Na}}$ channels: data from an inside-out membrane patch containing a single $\mathrm{K}_{\mathrm{Na}}$ channel. $V_{m}$ equaled $-40 \mathrm{mV}$ and $\left[\mathrm{Na}^{+}\right]_{i}$ was 150 mM. Solid lines indicate closed levels. $a$. In the absence of drug, the channel was open about $50 \%$ of the time. $b$, After $50 \mu \mathrm{M} d$-TC was added to the cytoplasmic surface, the channel was open only $6 \%$ of the time. The channel activity returned to control levels shortly after removing $d$-TC (not shown). 
a

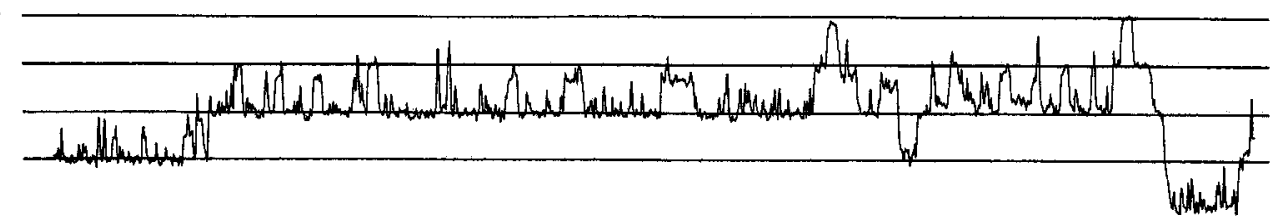

b

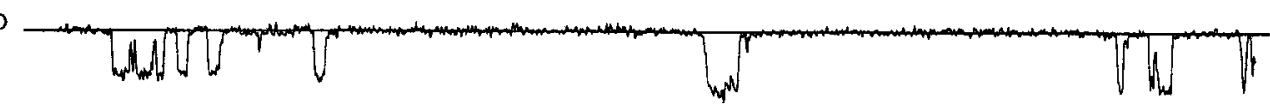

Figure 11. The piperidine R56865 blocks $\mathrm{K}_{\mathrm{Na}}$ channels: data from a patch containing at least four $\mathrm{K}_{\mathrm{Na}}$ channels. $V_{m}$ equaled $-43 \mathrm{mV}$ and $\left[\mathrm{Na}^{+}\right]_{i}$ was 150 mM. The solid lines indicate closed levels for the individual channels. $a$, In the absence of drug, superimposed channel openings are common. $b$, In the presence of $2.5 \mu \mathrm{M}$ R56865, the channels open less often. $c$, Superimposed channel openings occur again after washout of the drug. Note, however, that the overall channel activity is lower than control because of channel rundown (see Results for details).

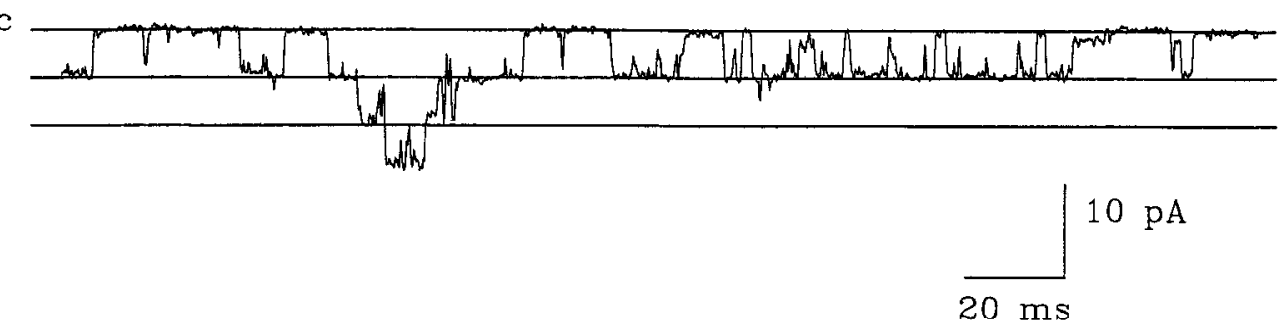

$\mathrm{Na}^{+}$channel blocker TTX $(1-10 \mu \mathrm{M}$; see Fig. $3 e)$, the $\mathrm{K}_{\mathrm{Ca}}$ channel blocker charybdotoxin $(0.01-10 \mu \mathrm{M})$, nor strophanthidin ( $1 \mathrm{mM}$; $n=2$ ), which inhibits the $\mathrm{Na}^{+} / \mathrm{K}^{+}$pump, blocked $\mathrm{K}_{\mathrm{Na}}$ channels when applicd to cither the internal (using inside-out membrane patches) or external (using outside-out membrane patches) membrane surfaces.

\section{$P_{\mathrm{o}}$ decreases with time in detached patches}

In a typical experiment using the inside-out patch configuration and an $\left[\mathrm{Na}^{+}\right]_{i}$ equal to $150 \mathrm{mM}$, the $P_{o}$ (or the $N P_{o}$ ) decreased over a period of time lasting from a few tens of seconds to up to $5 \mathrm{hr}$. An example of rapid rundown of $\mathrm{K}_{\mathrm{Na}}$ channel activity, with complete cessation of activity by 2 min after patch excision, is shown in Figure 12. Plots of $N P_{o}$ as a function of time after patch excision for several patches (Fig. 13) illustrate the variability in time course of rundown observed, even in a single culture dish on $1 \mathrm{~d}$. Variability was greater among groups of neurons cultured from different litters of rats on different days than from neurons of the same culture date. The length of time in culture (7-28 d) did not influence the extent or time course of rundown (although we did not extensively test cells younger than $6 \mathrm{~d}$ in culture). Often, the $P_{o}$ would decrease until virtually no channel gating was recorded. In these patches, channel activity could be recovered temporarily by increasing $\left[\mathrm{Na}^{+}\right]_{i}$; how-

a

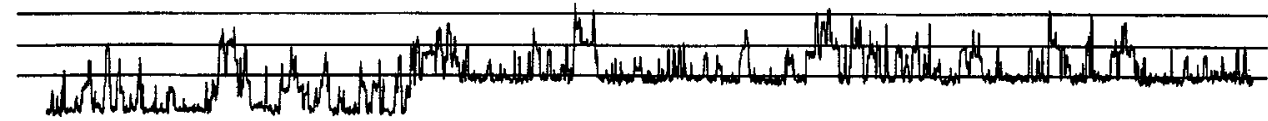

$\mathrm{b}$

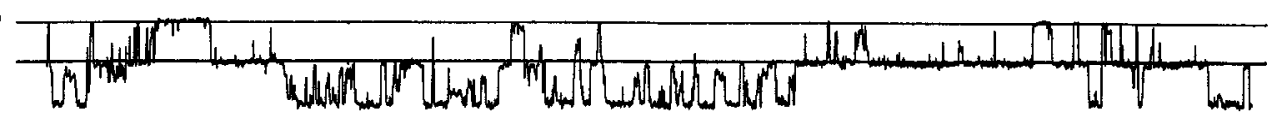

Figure 12. $\mathrm{K}_{\mathrm{Na}}$ channel rundown: Data from a four channcl patch showing a rapid decrease in channel activity following membrane patch excision. $\left[\mathrm{Na}^{+}\right]_{i}$ equaled $150 \mathrm{~mm},\left[\mathrm{~K}^{+}\right]_{0} /\left[\mathrm{K}^{+}\right]_{i}$ equaled $150 / 0$, and $V_{m}$ was $-40 \mathrm{mV}$. Inward current through the open channel was shown as downward deflections from the baseline. Solid lines indicate closed levels. Channel activity was high immediately after patch excision $(a)$, but was lower at $30 \mathrm{sec}(b)$ and $60 \mathrm{sec}(c)$ postexcision. No openings were seen after about $90 \sec (d)$.

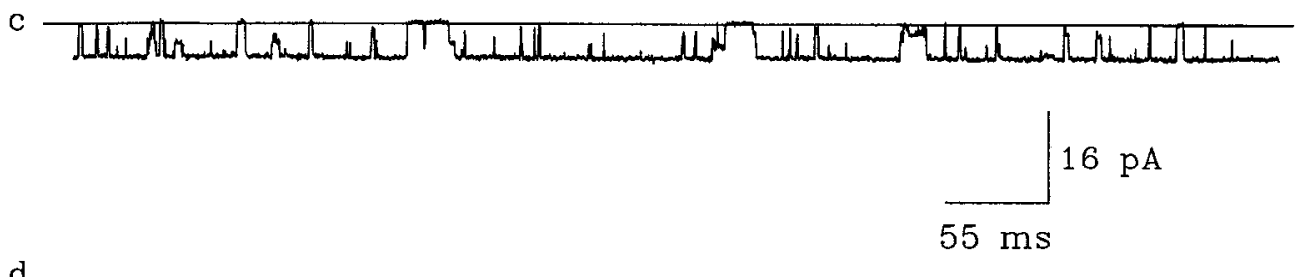


ever, channel activity again quickly fell to zero as the channels became insensitive to the higher $\left[\mathrm{Na}^{+}\right]_{i}$.

Rundown was not activity dependent; that is, it did not depend on the channel opening a given number of times. This was tested in the following way. Experiments were performed on neurons of the same culture datc to climinate some of the variability seen among cultures as detailed above. Control patches were excised into a $150 \mathrm{mM}\left[\mathrm{Na}^{+}\right]_{i}$ solution and $N P_{o}$ was measured to determine the time course of rundown. In this set of control experiments, rundown occurred rapidly so that $N P_{o}$ fell from values near 0.8 to almost 0 after about 10 min postexcision. Then, patches taken from other neurons of the same culture date were excised immediately into a $0 \mathrm{mM}\left[\mathrm{Na}^{+}\right]_{i}$ solution to prevent channel activity. After $30 \mathrm{~min},\left[\mathrm{Na}^{+}\right]_{i}$ was increased to $150 \mathrm{mM}$ to induce channel openings. If rundown was activity dependent, then we would have expected that introduction of $\left[\mathrm{Na}^{+}\right]_{;}$would result in about the same average $N P_{o}$ seen in the control patches immediately following excision into $150 \mathrm{mM}$ $\left[\mathrm{Na}^{+}\right]_{\text {. }}$. This was not the case. Channel activity was abnormally low or absent in the test patches after introduction of $150 \mathrm{mM}$ $\left[\mathrm{Na}^{+}\right]_{i}$ following a $30 \mathrm{~min}$ preincubation in $0 \mathrm{mM}\left[\mathrm{Na}^{+}\right]_{i}$, suggesting that rundown is not influenced by prior channel activity (or lack thereof).

We do not know what causes rundown. One possibility is that a cytoplasmic intermediate needed for prolonged channel activity is lost upon membrane excision. This is supported by our finding that channels in on-cell patches (in the presence of veratridine) do not show the rundown phenomenon. If some factor essential for gating is lost upon excision of the patch, then one would expect that gating would be modulated by adding an exogenous factor. We tested scveral possible modulators for their ability to influence channel gating behavior. Channel activity recorded from inside-out membrane patches was not affected by application of cAMP, cGMP, ATP (all at $1 \mathrm{mM}$ ), cAMP-dependent protein kinase with $1 \mathrm{mM} \operatorname{ATP}(n=2)$, or protein kinase $\mathrm{C}(n=2)$ to the internal membrane surface. Furthermore, none of these paradigms prevented channel rundown. Changing the temperature from about $25^{\circ} \mathrm{C}$ to $37^{\circ} \mathrm{C}$ did not affect the time course of rundown in inside-out patches. Forskolin $(50 \mu \mathrm{M})$, a membrane-permeable activator of adenyl cyclase, did not affect $\mathrm{K}_{\mathrm{Na}}$ channel activity recorded from oncell patches in the presence of veratridine $(n=3)$. Likewise, a $1-10 \mathrm{hr}$ preincubation in pertussis toxin $(200-400 \mathrm{ng} / \mathrm{ml}) \mathrm{did}$ not affect the ability of veratridine to activate $\mathrm{K}_{\mathrm{Na}}$ channels. Forskolin or pertussis toxin pretreatment also did not prevent channel rundown upon patch excision.

\section{$K_{N a}$ channels in thin slices of olfactory bulb}

$\mathrm{K}_{\mathrm{Na}}$ channels were recorded from visually identified neurons in the mitral cell body layer of thin slices of olfactory bulb. $\mathrm{K}_{\mathrm{Na}}$ channels identical to those of cultured olfactory bulb neurons were activated in inside-out patches by $150 \mathrm{~mm}\left[\mathrm{Na}^{+}\right]_{i}$. Channel activity decreased to zero when $\left[\mathrm{Na}^{+}\right]_{i}$ was replaced with $\left[\mathrm{K}^{+}\right]_{i}$ but was not affected by changes in $\left[\mathrm{Ca}^{2+}\right]_{i}$. The channel behavior resembled that of $\mathrm{K}_{\mathrm{Na}}$ channels of cultured olfactory bulb neurons with respect to the presence of multiple substates and the occurrence of rundown. $d-\mathrm{TC}(60 \mu \mathrm{M})$ applied to the internal surface of the membrane blocked the channel. $\mathrm{K}_{\mathrm{Na}}$ channels could also be recorded in on-cell patches from mitral neurons after addition of veratridine (10-60 $\mu \mathrm{M})$ to the bath solution ( $n$ $=3$ ). Thus far, in six attempts we have not observed $\mathrm{K}_{\mathrm{Na}}$ channels in granule cell neurons in thin slices.

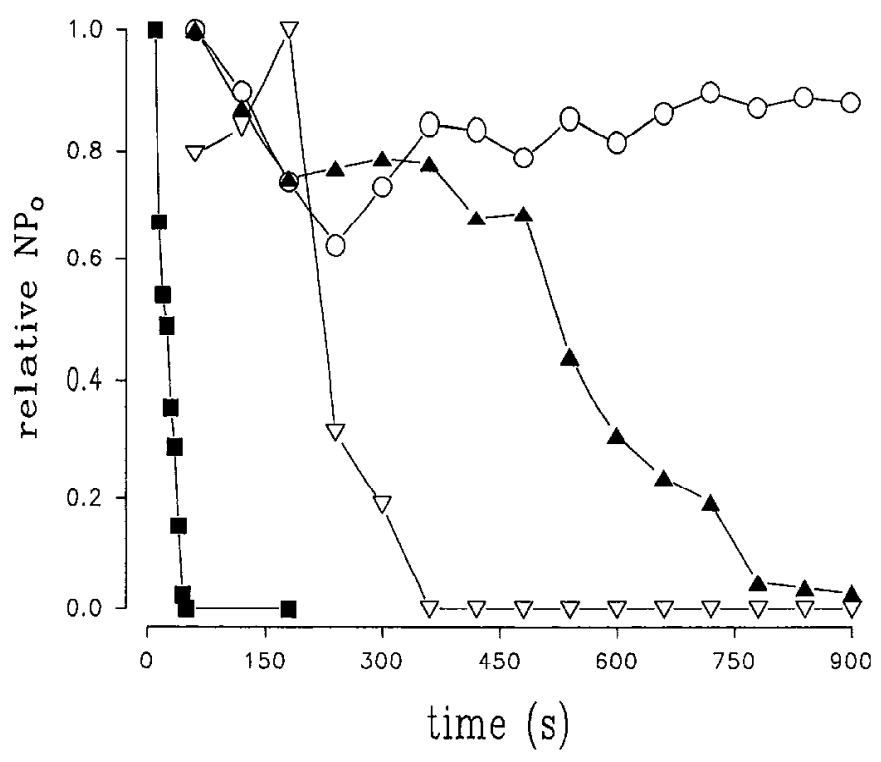

Figure 13. Variable rates of channel rundown. $N P_{o}$ values for four different patches (different symbols) as a function of time after patch excision to the inside-out configuration. $N P_{o}$ values were calculated for $5 \sec (\square)$ or $60 \sec (\nabla, \Delta, O)$ intervals and were normalized to the maximum $N P_{o}$ level for each patch. $\left[\mathrm{Na}^{+}\right]_{i}$ equaled $150 \mathrm{mM},\left[\mathrm{K}^{+}\right]_{o} /\left[\mathrm{K}^{\prime}\right]_{i}$ equaled $150 / 0$, and $V_{m}$ was $-40 \mathrm{mV}$ for all patches. Three of these patches $(\nabla, \Delta, O)$ were taken from neurons in a single culture dish on the same day; the other $(\square)$ is the patch whose channel activity is illustrated in Figure 12. The kinetic analysis in Figures 6 and 7 was done on patches exhibiting stable kinetic behavior, such as the one depicted with $O$ here.

\section{Whole-cell currents}

Current flow through $\mathrm{K}_{\mathrm{Na}}$ channels may contribute to a brief outward current that follows the voltage-activated $\mathrm{Na}^{+}$current in some preparations (Bader et al., 1985; Hartung, 1985; Dryer et al., 1989; but see also Dryer, 1991). Whole-cell voltage clamp of cultured rat olfactory bulb neurons failed to demonstrate any transient outward current resembling the $\mathrm{K}_{\mathrm{Na}}$ whole-cell current of other tissues except when very high concentrations ( $\geq 50 \mathrm{mM}$ ) of $\mathrm{Na}^{+}$were included in the pipette solution. When the pipette contained $30 \mathrm{mM} \mathrm{Na}{ }^{+}$, the $\left[\mathrm{Na}^{+}\right]_{i}$ used to evoke whole-cell $\mathrm{K}_{\mathrm{Na}}$ current in experiments on other tissues (see Discussion), a step depolarization to $-30 \mathrm{mV}$ from a resting $V_{m}$ of $-80 \mathrm{mV}$ resulted in an inward $\mathrm{Na}^{+}$current only. Only when the pipette contained $50 \mathrm{~mm}$ or more $\mathrm{Na}^{+}$was the inward $\mathrm{Na}^{+}$current followed by a transient outward current that lasted about 5-10 msec. Both inward and outward currents were absent after superfusion of TTX (100 nM), and both currents returned after washout of TTX.

\section{Discussion}

$\mathrm{K}_{\mathrm{Na}}$ channels have previously been recorded from mammalian heart (Kameyama et al., 1984; Luk and Carmeliet, 1990; Wang et al., 1991) and from nonmammalian nervous tissue (see Martin and Dryer, 1989; Kubota and Saito, 1991; Saito and Wu, 1991). In mammalian brain, voltage-clamp currents that are thought to be $\mathrm{K}_{\mathrm{Na}}$ currents have been reported (Constanti and Sim, 1987; Schwindt et al., 1989). We report here recordings of single $\mathrm{K}_{\mathrm{Na}}$ channel activity from mammalian CNS. Such singlechannel measurements eliminate the possibility of voltage-clamp artifacts (see Dryer, 1991) and provide unequivocal evidence 
for a population of $\mathrm{K}^{+}$-selective ion channels that are activated by $\mathrm{Na}_{i}$. These channels are present in neurons from a variety of regions of the rat brain, although their density appears to be the highest in olfactory bulb (T. M. Egan, D. Dagan, J. Kupper, and I. B. Levitan, unpublished observations). The $\mathrm{K}_{\mathrm{Na}}$ channel was the predominant $\mathrm{K}^{+}$-selective channel recorded from insideout patches of olfactory bulb neurons when $\left[\mathrm{Na}^{+}\right]_{i}$ was greater than about $10-20 \mathrm{~mm}$ and $V_{m}$ was hyperpolarized. It was easily differentiated from other $\mathrm{K}^{+}$channels by its conductance and gating behavior and by the presence of several distinct substates. Most patches contained several $K_{\mathrm{Na}_{\mathrm{a}}}$ channels, and it was not unusual to have four or more actively gating $\mathrm{K}_{\mathrm{Na}}$ channels in a patch of membrane enclosed by the 1-2 $\mu \mathrm{m}$ diameter tip of the recording electrode. If, as the numbers imply, the density of $\mathrm{K}_{\mathrm{Na}}$ channels is high in these neurons, then several important questions about some of the unusual properties of this channel come to mind.

\section{Regulation of gating by $\left[\mathrm{Na}^{+}\right]_{\mathrm{i}}$}

$\mathrm{K}_{\mathrm{Na}}$ channels opened when $\left[\mathrm{Na}^{+}\right]_{i}$ exceeded some minimal concentration, above which the $P_{o}$ depended on $\left[\mathrm{Na}^{+}\right]_{i}$. One important question is why the channel is relatively insensitive to its major activator, $\left[\mathrm{Na}^{+}\right]_{i}$. Relatively little $\mathrm{Ca}^{2+}{ }_{i}$ (tens or hundreds of nanomolar) is needed to activate $\mathrm{K}_{\mathrm{Ca}}$ channels. However, we needed at least $10-20 \mathrm{mM} \mathrm{Na}^{+}$to cause a noticeable activation of $\mathrm{K}_{\mathrm{Na}}$ channels in experiments on inside-out membrane patches, and even higher concentrations to activate the channel half-maximally. These data agree with measurements of the $\left[\mathrm{Na}^{+}\right]_{i}$ sensitivity of $\mathrm{K}_{\mathrm{Na}}$ channels of other tissues. However, it seems unlikely that such high $\left[\mathrm{Na}^{+}\right]_{i}$ is ever reached in healthy, intact neurons, even at the peak of the action potential. Thus, it seems possible that the true $\left[\mathrm{Na}^{+}\right]_{i}$ sensitivity of the channel is higher. Several observations suggest that this is indeed the case. First, $\mathrm{K}_{\mathrm{Na}}$ channels had a wide range of sensitivity to $\left[\mathrm{Na}^{+}\right]_{i}$. For example, while $20 \mathrm{mM} \mathrm{Na}^{+}{ }_{i}$ often induced $\mathrm{K}_{\mathrm{Na}}$ channel activity (Fig. 1), in some experiments $\left[\mathrm{Na}^{+}\right]_{i}$ had to excced $60 \mathrm{~mm}$ before significant activation occurred. Further, the $P_{o}$ measured immediately upon excision into $150 \mathrm{mM}\left[\mathrm{Na}^{+}\right]_{i}$ also varied greatly for our sample of the $K_{\mathrm{Na}}$ channel population, ranging from 0.2 to about 0.8 . While the activities of channels of high initial $P_{o}$ values were not increased by further raising $\left[\mathrm{Na}^{+}\right]_{i}$ (up to $180 \mathrm{mM}$ ), $\mathrm{K}_{\mathrm{Na}}$ channels that were fairly insensitive to $150 \mathrm{~mm}\left[\mathrm{Na}^{+}\right]_{i}\left(P_{o}\right.$ values $\left.<0.8\right)$ did respond to additional $\left[\mathrm{Na}^{+}\right]_{i}$. Also, in patches containing many $\mathrm{K}_{\mathrm{Na}}$ channels, $N P_{o}$ continued to increase even at the highest $\left[\mathrm{Na}^{+}\right]_{i}$ tested $(180 \mathrm{~mm})$. This variability makes it difficult to pinpoint the true $\left[\mathrm{Na}^{+}\right]_{i}$ sensitivity of the channel. We believe that the variable $\left[\mathrm{Na}^{+}\right]_{i}$ sensitivity may be related to the phenomenon of rundown.

Rundown was a prominent feature of many if not all $\mathrm{K}_{\mathrm{Na}}$ channels in off-cell patches. Channel activity, which was normally high immediately following excision, decreased with time, such that the $P_{o}$ (or the $N P_{o}$ ) sometimes fell to almost zero in just a few minutes (Fig. 12). While the very rapid rundown depicted in Figure 12 was observed infrequently, channel activity did decrease during most experiments (Fig. 13). Therefore, because it took $15-30 \mathrm{~min}$ to construct the $\left[\mathrm{Na}^{+}\right]_{i}$ versus $P_{o}$ curves, rundown probably resulted in an underestimate of the true $\left[\mathrm{Na}^{+}\right]_{i}$ sensitivity. How much we have underestimated the $\left[\mathrm{Na}^{+}\right]_{i}$ sensitivity is unknown. We noticed that channel activity was always very high in the first few seconds following patch excision, after which it would quickly settle to a new level from which it would fall more slowly with time. This very rapid decrease in channel activity immediately following excision was difficult to quantify, and may result from the same phenomenon responsible for the slower phase of rundown that we observed routinely. Thus, a degree of rundown may have occurred even in those channels that showed a relatively high initial $\left[\mathrm{Na}^{+}\right]_{i}$ sensitivity, and even here $\left[\mathrm{Na}^{+}\right]_{i}$ versus $P_{o}$ curves may have underestimated the true $\left[\mathrm{Na}^{+}\right]_{i}$ sensitivity.

Finally, $\left[\mathrm{Na}^{+}\right]_{i}$ versus $P_{o}$ was measured routinely at a $V_{m}$ of -40 to $-60 \mathrm{mV}$. Other experiments showed that $\mathrm{K}_{\mathrm{Na}}$ channels are voltage dependent, and opened more often at depolarized $V_{m}$ at any one $\left[\mathrm{Na}^{+}\right]_{i}$. We measured $\left[\mathrm{Na}^{+}\right]_{i}$ sensitivity at negative $V_{m}$ because we found it difficult to maintain gigaohm seals when patches were held at positive $V_{m}$ for more than a few minutes. Also, single-channel currents were more difficult to measure at positive $V_{m}$ because of the $\mathrm{Na}^{+}$block of $\mathrm{K}_{\mathrm{Na}}$ channels that gave rise to inward rectification. We expect that $\mathrm{K}_{\mathrm{Na}}$ channels would appear to be more sensitive to $\left[\mathrm{Na}^{+}\right]_{i}$ if this parameter could be measured accurately at positive $V_{m}$. This may be important, because $\left[\mathrm{Na}^{+}\right]_{i}$ would be expected to be highest at the peak of the action potential, a time at which the cell would also be very depolarized.

\section{What is the function of $K_{N a}$ in olfactory bulb neurons?}

Several possible functions have been postulated for $\mathrm{K}_{\mathrm{Na}}$ channels of other tissues. These include a role in repolarizing the cell following an action potential (Bader et al., 1985; Hartung, 1985), contributing to the generation of the resting $V_{m}$ (Dryer et al., 1989), protecting the cell from $\left[\mathrm{Na}^{+}\right]_{i}$ or $\left[\mathrm{Ca}^{2+}\right]$ overload (Kameyama et al., 1984; Luk and Carmeliet, 1990), and reducing excitability during maintained subthreshold excitation (Schwindt et al., 1989). The channel may also play a role in neurotransmitter modulation of firing patterns (Constanti and Sim, 1987; Foehring et al., 1989). So far, experiments designed to test two of these ideas have not defined a role for the $\mathrm{K}_{\mathrm{Na}}$ channel in olfactory bulb neurons. First, it seems unlikely that the channel normally contributes to the resting $V_{m}$ because we never saw an active channel in on-cell patches (except in the presence of veratridine). Second, whole-cell voltage clamp of cultured olfactory bulb neurons failed to implicate $\mathrm{K}_{\mathrm{Na}}$ currents in repolarization following inward $\mathrm{Na}^{+}$currents. In other tissues, step depolarizations from appropriate resting $V_{m}$ produce large voltage-dependent inward $\mathrm{Na}^{+}$currents that are immediately followed by transient outward $\mathrm{K}^{+}$currents (Bader et al., 1985; Hartung, 1985; Dryer et al., 1989). It has been suggested that this outward current results from current flow through $\mathrm{K}_{\mathrm{Na}}$ channels. However, recent evidence has shown that these transient outward currents may result from an artifact of the experimental procedure and not from activation of $\mathrm{K}_{\mathrm{Na}}$ channels (Dryer, 1991). Using the same conditions that produced outward currents in other tissues (i.e., $30 \mathrm{~mm}\left[\mathrm{Na}^{+}\right]_{i}$ ), we did not record a transient outward current following induction of inward $\mathrm{Na}^{+}$current. $\Lambda \mathrm{s}$ our data suggest that the $K_{\mathrm{Na}}$ channels may be controlled by an intracellular intermediate, which is lost in off-cell patches, one explanation for our failure to record whole-cell $\mathrm{K}_{\mathrm{Na}}$ currents may be that the concentration of this same intracellular intermediate decreases as a consequence of the perfusion of the inside of the neurons by the contents of the whole-cell patch electrode.

The idea that the $\mathrm{K}_{\mathrm{Na}}$ channel is affected by neurotransmitters is intriguing. Most of the incoming synaptic input to the mitral cells occurs on the distal dendrites. If the $\mathrm{K}_{\mathrm{Na}}$ channel is present 
in the dendrites, and if the channel is, as suggested, more sensitive to $\left[\mathrm{Na}^{+}\right]_{i}$ than we have so far been able to measure, then it is possible that $\left[\mathrm{Na}^{+}\right]_{i}$ may rise in response to an excitatory neurotransmitter to a level high enough to activate $\mathrm{K}_{\mathrm{Na}}$ channels. Likewise, if, as suggested by the presence of rundown, the channel activity is controlled by some diffusible substance, then it is feasible that a neurotransmitter that influences the postsynaptic concentration of this substance would affect $\mathrm{K}_{\mathrm{Na}}$ channel gating.

\section{What do we know about rundown?}

A defining characteristic of the $\mathrm{K}_{\mathrm{Na}}$ channel of rat olfactory bulb neurons was the gradual decrease in channel activity recorded from off-cell patches. Rundown does not appear to be a general feature of $K_{\mathrm{Na}}$ channels of most other tissues, although it is seen in channels in inside-out patches of cultured chick olfactory bulb neurons (S. E. Dryer, personal communication) and in Xenopus oocytes (J. Kupper and I. B. Levitan, unpublished observations). We do not know at present what causes the activity to decrease with time. One obvious explanation is that some diffusible intracellular substance that is required for the maintenance of channel gating is lost upon excision of the patch. This hypothesis is strengthened by the observation that on-cell recordings of $\mathrm{K}_{\mathrm{Na}}$ channels in veratridine-treated cells did not show rundown. The outcome of losing the diffusible substance apparently is a shift in the sensitivity of the channel to $\left[\mathrm{Na}^{+}\right]_{i}$, as channel activity is momentarily recovered after rundown by addition of high $\left[\mathrm{Na}^{+}\right]_{i}$, showing that the channel is still able to gate but requires a higher $\left[\mathrm{Na}^{+}\right]_{i}$ to do so. If the channel requires some chemical to continue gating, then it is expected that the channel gating would be affected in off-cell patches by adding this chemical to the solution bathing the internal surface of the membrane. Several preliminary attempts at adding back putative channel modulators have so far failed to affect channel gating or rundown, and the diffusible intracellular substance remains to be identified. By understanding what causes rundown we expect to gain insight into how the cell modulates the activity of these channels.

\section{References}

Bader CR, Bernheim L, Bertrand D (1985) Sodium-activated potassium current in culturcd avian neurones. Nature 317:540-542.

Baughman RW, Huettner JE, Jones KA, Khan AA (1991) Cell culture of neocortex and basal forebrain from postnatal rats. In: Culturing nerve cells (Banker G, Goslin K, eds), pp 227-249. Cambridge, MA: MIT Press.

Constanti A, Sim JA (1987) Calcium-dependent potassium conductance in guinea-pig olfactory cortex neurones in vitro. J Physiol (Lond) 387:173-194.

Døving KB (1987) Response properties of neurons in the rat olfactory bulb to various parameters of odour stimulation. Acta Physiol Scand 130:285-298.

Dryer SE (1991) $\mathrm{Na}^{+}$-activated $\mathrm{K}^{+}$channels and voltage-evoked ionic currents in brain stem and parasympathetic neurones of the chick. J Physiol (Lond) 435:513-532.

Dryer SE, Fujii JT, Martin AR (1989) $\mathrm{A} \mathrm{Na}^{+}$-activated $\mathrm{K}^{+}$current in cultured brain stem neurones from chicks. J Physiol (Lond) 410:283296.

Edwards FA, Konnerth A, Sakmann B, Takahashi T (1989) A thin slice preparation for patch clamp recordings from neurones of the mammalian central nervous system. Pfluegers Arch 414:600-612.

Egan TM, Dagan D, Levitan IB (1990) Calcium and sodium activate different potassium channels in cultured rat olfactory bulb neurons. Biophys J 57:313a.
Foehring RC, Schwindt PC, Crill WE (1989) Norepinephrine selectively reduces slow $\mathrm{Ca}^{2+}$ - and $\mathrm{Na}^{+}$-mediated $\mathrm{K}^{+}$currents in cat neocortical neurons. J Neurophysiol 61:245-256.

Frosch MP, Dichter MA (1984) Physiology and pharmacology of olfactory bulb neurons in dissociated cell culture. Brain Res 290:321332.

Haimann C, Bernheim L, Bertrand D, Bader CR (1990) Potassium current activated by intracellular sodium in quail trigeminal ganglion neurones. J Gen Physiol 95:961-979.

Hamill OP, Marty A, Neher E, Sakmann B, Sigworth FJ (1981) Improved patch clamp techniques for high-resolution current recording from cells and cell-free membrane patches. Pfluegers Arch 391:85100.

Hamilton KA, Kauer JS (1985) Intracellular potentials of salamander mitral/tufted neurons in response to odor stimulation. Brain Res 338: 181-185.

Hamilton KA, Kauer JS (1989) Patterns of intracellular potentials in salamander mitral/tufted cells in response to odor stimulation. J Neurophysiol 62:609-625.

Hartung K (1985) Potentiation of a transient outward current by $\mathrm{Na}^{+}$ influx in crayfish neurones. Pfluegers Arch 404:41-44.

Huettner JE, Baughman RW (1986) Primary culture of identified neurons from the visual cortex of postnatal rats. J Neurosci 6:3044-3060.

Jahr CE, Nicoll RA (1982) An intracellular analysis of dendrodendritic inhibition in the turtle in vitro olfactory bulb. J Physiol (Lond) 326: 213-234.

Kameyama M, Kakei M, Sato R, Shibasaki T, Matsuda H, Irisawa H (1984) Intracellular $\mathrm{Na}^{+}$activates a $\mathrm{K}^{+}$channel in mammalian cardiac cells. Nature 309:354-356.

Kauer JS (1974) Kesponse patterns of amphibian olfactory bulb neurones to odour stimulation. J Physiol (Lond) 243:695-715.

Kauer JS (1987) Coding in the olfactory system. In: Neurobiology of taste and smell (Finger TE, Silver WL, eds), pp 205-231. New York: Wiley-Interscience.

Kauer JS (1991) Contributions of topography and parallel processing to odor coding in the vertebrate olfactory pathway. Trends Neurosci 14:79-85.

Kubota M, Saito N (1991) Sodium- and calcium-dependent conductances of neurones in the zebra finch hyperstriatum ventrale pars caudale in vitro. J Physiol (Lond) 440:131-142.

Latorre R, Oberhauser A, Labarca P, Alvarez O (1989) Varieties of calcium-activated potassium channels. Annu Rev Physiol 51:385399.

Luk HN, Carmeliet E (1990) $\mathrm{Na}^{+}$-activated $\mathrm{K}^{+}$current in cardiac cells: rectification, open probability, block and role in digitalis toxicity. Pfluegers Archiv 416:766-768.

Macrides F, Chorover SL (1972) Olfactory bulb units: activity correlated with inhalation cycles and odor quality. Science 175:84-87.

Mair RG (1982) Response properties of rat olfactory bulb neurones. J Physiol (Lond) 326:341-359.

Martin AR, Dryer SA (1989) Potassium channels activated by sodium. Q J Exp Physiol 74:1033-1041.

Meredith M (1986) Patterned response to odor in mammalian olfactory bulb: the influence of intensity. J Neurophysiol 56:572-597.

Mori K (1987) Membrane and synaptic properties of identified neurones in the olfactory bulb. Prog Neurobiol 29:275-320.

Partridge LD, Thomas RC (1976) The effects of lithium and sodium on the potassium conductance of snail neurones. J Physiol (Lond) 254:551-563.

Saito M, Wu C-F (1991) Expression of ion channels and mutational effects in giant Drosophila neurons differentiated from cell divisionarrested embryonic neuroblasts. J Neurosci 11:2135-2150.

Schwindt P, Spain WJ, Crill WE (1989) Long-lasting reduction of excitability by a sodium-dependent potassium current in cat neocortical neurons. J Neurophysiol 61:233-244.

Scott JW, Harrison TA (1987) The olfactory bulb: anatomy and physiology. In: Neurobiology of taste and smell (Finger TE, Silver WL, eds), pp 151-178. New York: Wiley-Interscience.

Shepherd GS, Greer CA (1990) Olfactory bulb. In: The synaptic organization of the brain, 3d ed (Shepherd GM, ed), pp 133-169. New York: Oxford UP.

Smart TG (1987) Single calcium-activated potassium channels recorded from cultured rat sympathetic neurones. J Physiol (Lond) 389: $337-360$. 
Trombley PQ, Westbrook GL (1990) Excitatory synaptic transmission in cultures of rat olfactory bulb. J Neurophysiol 64:598-606.

Wang Z, Kimitsuki T, Noma A (1991) Conductance properties of the $\mathrm{Na}^{+}$-activated $\mathrm{K}^{+}$channel in guinea-pig ventricular cells. J Physiol (Lond) 433:241-257.

Wellis DP, Scott JW (1990) Intracellular responses of identified rat olfactory bulb interneurons to electrical and odor stimulation. $J$ Neurophysiol 64:932-947.
Wellis DP, Scott JW, Harrison TA (1989) Discrimination among odorants by single neurons of the rat olfactory bulb. J Neurophysiol 61: 1161-1177.

Yamamoto C, Yamamoto T, Iwama K (1963) The inhibitory system in the olfactory bulb studied by intracellular recording. J Neurophysiol 26:403-415. 